Article

\title{
Comparison among Constituent Phases in Superlattice Metal Hydride Alloys for Battery Applications
}

\author{
Kwo-Hsiung Young ${ }^{1,2, *}$ (D) , Taihei Ouchi ${ }^{2}$, Jean Nei ${ }^{2}$ (D) , John M. Koch ${ }^{2}$ and Yu-Ling Lien ${ }^{3}$ \\ 1 Department of Chemical Engineering and Materials Science, Wayne State University, Detroit, MI 48202, USA \\ 2 BASF/Battery Materials-Ovonic, 2983 Waterview Drive, Rochester Hills, MI 48309, USA; \\ taihei.ouchi@basf.com (T.O.); jean.nei@basf.com (J.N.); john.m.koch@basf.com (J.M.K.) \\ 3 Department of Chemistry, Michigan State University, East Lansing, MI 48824, USA; yulinglien@gmail.com \\ * Correspondence: kwo.young@basf.com; Tel.: +1-248-293-7000
}

Academic Editor: Andreas Jossen

Received: 14 September 2017; Accepted: 18 October 2017; Published: 31 October 2017

\begin{abstract}
The effects of seven constituent phases- $\mathrm{CeNi}_{3}, \mathrm{NdNi}_{3}, \mathrm{Nd}_{2} \mathrm{Ni}_{7}, \mathrm{Pr}_{2} \mathrm{Ni}_{7}, \mathrm{Sm}_{5} \mathrm{Ni}_{19}, \mathrm{Nd}_{5} \mathrm{Co}_{19}$, and $\mathrm{CaCu}_{5}$ - on the gaseous phase and electrochemical characteristics of a superlattice metal hydride alloy made by induction melting with a composition of $\mathrm{Sm}_{14} \mathrm{La}_{5.7} \mathrm{Mg}_{4.0} \mathrm{Ni}_{73} \mathrm{Al}_{3.3}$ were studied through a series of annealing experiments. With an increase in annealing temperature, the abundance of non-superlattice $\mathrm{CaCu}_{5}$ phase first decreases and then increases, which is opposite to the phase abundance evolution of $\mathrm{Nd}_{2} \mathrm{Ni}_{7}$-the phase with the best electrochemical performance. The optimal annealing condition for the composition in this study is $920^{\circ} \mathrm{C}$ for $5 \mathrm{~h}$. Extensive correlation studies reveal that the $\mathrm{A}_{2} \mathrm{~B}_{7}$ phase demonstrates higher gaseous phase hydrogen storage and electrochemical discharge capacities and better battery performance in high-rate dischargeability, charge retention, and cycle life. Moreover, the hexagonal stacking structure is found to be more favorable than the rhombohedral structure.
\end{abstract}

Keywords: metal hydride (MH); nickel/metal hydride (Ni/MH) battery; hydrogen absorbing alloy; electrochemistry; superlattice alloy

\section{Introduction}

Misch metal (Mm, a mixture of more than one rare earth element)-based superlattice metal hydride $(\mathrm{MH})$ alloys are very important for today's nickel/metal hydride $(\mathrm{Ni} / \mathrm{MH})$ batteries, because of their higher hydrogen storage (H-storage) capacity, better high-rate dischargeability (HRD) capability, superior low-temperature and charge retention performances, and improved cycle stability [1-8]. The three main components in the superlattice alloy can be classified by chemical stoichiometry-or more precisely, the $\mathrm{B} / \mathrm{A}$ ratio- and they are $\mathrm{AB}_{3}, \mathrm{~A}_{2} \mathrm{~B}_{7}$, and $\mathrm{A}_{5} \mathrm{~B}_{19}$. In each component, there are two different types of structures-hexagonal and rhombohedral, depending on the stacking sequence for the $\mathrm{A}_{2} \mathrm{~B}_{4}$ slabs (illustrated in pink in Figure 1). Each $\mathrm{A}_{2} \mathrm{~B}_{4}$ slab shifts on the $a b$-plane by $1 / 3 \vec{a}$ and $1 / 3$ $\vec{b}$ from its neighbor. Studies on superlattice alloys began with the structure [9] and gaseous phase (GP) $\mathrm{H}$-storage characteristics of the single rare earth element (RE)-based $\mathrm{AB}_{3}$ alloys [10-12] and soon shifted to the $\mathrm{Mm}$-based $\mathrm{A}_{2} \mathrm{~B}_{7}$ chemistry for battery applications [13-16]. Some researchers continued to work on RE-based $\mathrm{AB}_{3}$ chemistry for its basic electrochemical (EC) properties [17-22]. In the meantime, RE-based $A_{5} B_{19}$ was also highly promoted for battery applications [23-27]. Several comparative works on the EC performances of various superlattice phases were previously reported and are summarized as follows. In a ( $\mathrm{LaMg}) \mathrm{Ni}_{x}(x=3,3.5$, and 3.8) system, the capacity decreased, and both HRD and cycle stability increased with the increase of $x$ from 3 to 3.5 and finally 3.8 [28]. In a (LaY)(NiMnAl $)_{x}$ $(x=3,3.5$, and 3.8) system, both capacity and cycle stability reached the maximum at $x=3.5$, and 
HRD increased with the increase in $x$ [29]. The EC properties of the Mm-based $\mathrm{AB}_{x}$ (where $\mathrm{A}$ is $\mathrm{Mm}$, $\mathrm{B}$ is a combination of several transition metals and $\mathrm{Al}$, and $x=2,3,3.5,3.8$, and 5) were compared, and $A_{2} B_{7}$ showed the best overall performance [30,31], which prompted many investigations in the $A_{2} B_{7}$ superlattice alloys [32-37]. However, no data were provided to support the comparative work. Therefore, in this work we detail the correlations between the constituent phase abundances and various properties.

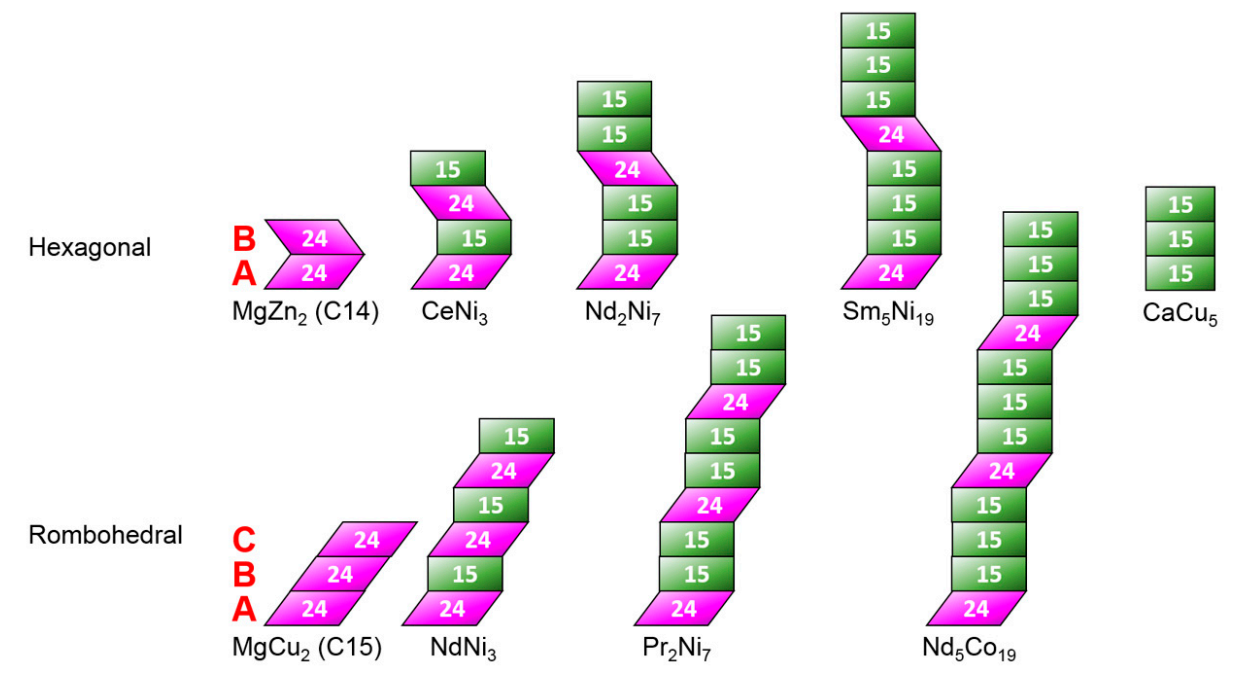

Figure 1. Stacking sequences along the $c$-axis direction of various hexagonal and rhombohedral structures available for the superlattice metal hydride alloys.

Annealing has been used to effectively alter the phase components in the $\mathrm{AB}[38,39], \mathrm{AB}_{2}$ [40-43], $\mathrm{AB}_{3}$ [44-47], $\mathrm{A}_{2} \mathrm{~B}_{7}$ [48-51], $\mathrm{A}_{5} \mathrm{~B}_{19}$ [52], $\mathrm{AB}_{5}$ [53-55], $\mathrm{A}_{8} \mathrm{~B}_{21}$ [56,57], and body-centered-cubic (bcc) [58] $\mathrm{MH}$ alloys. According to first-principle calculations on superlattice $\mathrm{MH}$ alloy systems, the preferable phase abundance can be influenced by the starting composition and annealing condition $[59,60]$. For example, the $A_{2} B_{7}$ phase is more stable than the mixture of the $A_{3}$ and $A B_{5}$ phases in the $\mathrm{La}_{3} \mathrm{MgNi}_{14}$ alloy, however, the opposite is true in the $\mathrm{La}_{2} \mathrm{CeMgNi}_{14}$ alloy [60]. Therefore, while annealing increased the $\mathrm{A}_{2} \mathrm{~B}_{7}$ phase abundance in the La-based superlattice alloy [61], it promoted phase segregation in the LaPrNd-based alloy [62]. Moreover, phase segregation is more prominent in the Mm-based (A is more than one RE element) superlattice alloys than in the RE-based (A is only one RE element) alloys. In this work, annealing is applied to engineer the abundances of constituent components in a SmLa-based superlattice alloy, and the correlations of phase abundances with the GP and EC properties are reported.

\section{Experimental Setup}

First, Eutectix (Troy, MI, USA) prepared a $250 \mathrm{~kg}$ ingot using the conventional induction melting method [31]. Five $2 \mathrm{~kg}$ ingot pieces were annealed in $1 \mathrm{~atm}$ atmosphere of $\mathrm{Ar}$ for $5 \mathrm{~h}$ at different temperatures. Each ingot was hydrided and then crushed and ground into the size of -200 mesh. Chemical compositions of ingots before and after annealing were verified with a Varian Liberty 100 inductively coupled plasma-optical emission spectrometer (ICP-OES, Agilent Technologies, Santa Clara, CA, USA). A Philips X'Pert Pro X-ray diffractometer (XRD, Amsterdam, The Netherlands) and a JEOL-JSM6320F scanning electron microscope (SEM, Tokyo, Japan) with energy dispersive spectroscopy (EDS) was used to conduct microstructure analysis. GP H-storage characteristics were evaluated with a Suzuki-Shokan multi-channel pressure-concentration-temperature system (PCT, Tokyo, Japan). Negative electrodes were fabricated by compacting the alloy powder onto an expanded nickel substrate through a roll mill without any binder. Half-cell measurements were performed using 
a CTE MCL2 Mini cell testing system (Chen Tech Electric MFG. Co., Ltd., New Taipei, Taiwan) with a partially pre-charged $\mathrm{Ni}(\mathrm{OH})_{2}$ positive electrode and a $30 \% \mathrm{KOH}$ electrolyte. The electrode was first charged with a current density of $100 \mathrm{~mA} \cdot \mathrm{g}^{-1}$ for $4 \mathrm{~h}$ and then discharged with a current density of $400 \mathrm{~mA} \cdot \mathrm{g}^{-1}$ until a cutoff voltage of $0.9 \mathrm{~V}$ was reached. More discharges at smaller current densities $\left(300,200,100,50\right.$, and $\left.5 \mathrm{~mA} \cdot \mathrm{g}^{-1}\right)$ with the same cutoff voltage were performed afterward with a $2 \mathrm{~min}$ rest in between. The sum of capacities from six discharge stages was used as the full discharge capacity. The HRD was defined as the ratio of the capacity obtained at the highest rate $\left(400 \mathrm{~mA} \cdot \mathrm{g}^{-1}\right) \mathrm{vs}$. full discharge capacity. A Solartron 1250 Frequency Response Analyzer (Solartron Analytical, Leicester, UK) with a sine wave amplitude of $10 \mathrm{mV}$ and a frequency range of $0.5 \mathrm{mHz}$ to $10 \mathrm{kHz}$ was used for the AC impedance measurement. A Digital Measurement Systems Model 880 vibrating sample magnetometer (MicroSense, Lowell, MA, USA) was used to measure the magnetic susceptibility of the alloy powder surface after activation, which was performed by immersing the powder in $30 \mathrm{wt} \%$ $\mathrm{KOH}$ solution at $100^{\circ} \mathrm{C}$ for $4 \mathrm{~h}$.

For the sealed cell testing, a C-size cylindrical cell was chosen. While the negative electrode was fabricated by dry compacting the alloy powder onto nickel mesh current collectors, the counter positive electrode was fabricated by pasting a mixture of $89 \%$ standard AP50 [63] with the composition of $\mathrm{Ni}_{0.91} \mathrm{Co}_{0.045} \mathrm{Zn}_{0.045}(\mathrm{OH})_{2}$ (BASF-Ovonic, Rochester Hills, MI, USA), $5 \mathrm{wt} \%$ Co powder, and $6 \% \mathrm{CoO}$ powder onto nickel foam substrates. Scimat 700/79 acrylic acid grafted polypropylene/polyethylene separators were used (Freudenberg Group, Weinheim, Germany). A 1.5 to 1.7 negative-to-positive capacity ratio cell design was used to maintain a good balance between the over-charge and over-discharge reservoirs [64]. A $30 \mathrm{wt} \% \mathrm{KOH}$ solution with $\mathrm{LiOH}(1.5 \mathrm{wt} \%)$ additive was used as the electrolyte. Formation was performed with a six-cycle process using a Maccor Battery Cycler (Maccor, Tulsa, OK, USA). Details of cell testing can be found in an earlier publication [65].

\section{Results and Discussion}

The design compositions for this study are presented in Table 1. Sm was chosen as the main RE element because it is relatively inexpensive (like La and $\mathrm{Ce}$ ) and less oxidable (for a comparison to other RE elements, see Table 7 in [31]). However, the metal-hydrogen bond strength of the Sm-based superlattice $\mathrm{MH}$ alloy is too weak $\left(\mathrm{Sm}_{2} \mathrm{Ni}_{7}\right.$ has a discharge capacity of $170 \mathrm{mAh} \cdot \mathrm{g}^{-1}$ [66]), and thus adding La is necessary to increase the storage capacity [67]. LaSm-based superlattice MH alloys with the $\mathrm{La} / \mathrm{Sm}$ ratio above 1 were previously reported. While the $\mathrm{AB}_{5}$ phase cannot be removed completely by annealing in those alloys, the $\mathrm{AB}_{5}$ phase abundance still decreased with the increase in Sm-content [27,68-72]. In this experiment, a $\mathrm{La} / \mathrm{Sm}$ ratio of 0.4 was adopted to attempt to suppress the $\mathrm{AB}_{5}$ phase abundance. Two common constituent elements used in the $\mathrm{AB}_{5} \mathrm{MH}$ alloy, $\mathrm{Mn}$ and $\mathrm{Co}$, are excluded in this study for better charge retention and cycle stability [1,73]. Al is included to prevent the hydrogenation-induced-amorphization in the superlattice $\mathrm{MH}$ alloys [36].

Table 1. Designed composition and ICP results in at $\%$. B/A is the ratio of the $\mathrm{B}$-atom (Ni and $\mathrm{Al})$ to the A-atom ( $\mathrm{La}, \mathrm{Sm}$, and $\mathrm{Mg})$.

\begin{tabular}{ccccccccc}
\hline Alloy & Annealing Temperature & Source & La & Sm & Mg & Ni & Al & B/A \\
\hline- & - & Design & 5.7 & 14.0 & 4.0 & 73.0 & 3.3 & 3.2 \\
A0 & - & ICP & 5.7 & 14.0 & 3.9 & 73.0 & 3.4 & 3.2 \\
A1 & $880^{\circ} \mathrm{C}$ & ICP & 6.0 & 14.5 & 4.2 & 72.1 & 3.2 & 3.0 \\
A2 & $900^{\circ} \mathrm{C}$ & ICP & 5.8 & 13.9 & 4.0 & 72.9 & 3.4 & 3.2 \\
A3 & $920^{\circ} \mathrm{C}$ & ICP & 5.8 & 13.9 & 4.0 & 73.0 & 3.3 & 3.2 \\
A4 & $940^{\circ} \mathrm{C}$ & ICP & 5.8 & 14.3 & 4.0 & 72.7 & 3.2 & 3.1 \\
A5 & $960^{\circ} \mathrm{C}$ & ICP & 5.8 & 14.5 & 4.0 & 72.5 & 3.2 & 3.1 \\
\hline
\end{tabular}

Five pieces of ingot from the induction melting were annealed at $880,900,920,940$, and $960{ }^{\circ} \mathrm{C}$ for $5 \mathrm{~h}$ in an Ar environment. Compositions of the as-cast (alloy A0) and annealed ingots (alloys A1 to A5) 
were measured by ICP, and the results are summarized in Table 1. ICP results reveal that the annealed ingots have similar Mg-content, but are slightly rich in La and lean in Ni.

\subsection{Microsctructure Analysis}

XRD patterns of alloys in this study are presented in Figure 2. These patterns show the typical multi-phase superlattice structures. By using the Jade 9.0 software (MDI, Livermore, CA, USA), we were able to deconvolute each pattern into its constituent phases, and the results are summarized in Table 2. One example of such deconvolution is plotted in Figure 3. There are two stacking structures for each stoichiometry $\left(\mathrm{AB}_{3}, \mathrm{~A}_{2} \mathrm{~B}_{7}\right.$, and $\left.\mathrm{A}_{5} \mathrm{~B}_{19}\right)$-hexagonal $(\mathrm{H})$ and rhombohedral $(\mathrm{R})$. Most of the phase transformations in the superlattice phases are through the peritectic reaction and are very sensitive to the annealing conditions (temperature and duration). From Table 2, it is clear that annealing initially suppresses the unwanted non-superlattice $A_{5}$ phase, which decreases both the capacity and HRD [72,73]. However, further increases in annealing temperature promotes the formation of $\mathrm{AB}_{5}$. Evolutions in phase stoichiometry $\left(x\right.$ value in $\left.\mathrm{AB}_{x}\right)$ and stacking structure (hexagonal vs. rhombohedral) with different annealing temperatures are plotted in Figure 4. Annealing first increases the $A_{2} B_{7}$ abundance at the expense the $A_{3}$ abundance, but further increases in annealing temperature decreases the $A_{2} B_{7}$ abundance. In comparison, the changes in $A_{5} B_{19}$ abundance are less obvious. For the stacking structure evolution, annealing first increases the hexagonal structure and then slowly decreases it as the annealing temperature increases (Figure $4 b$ ).

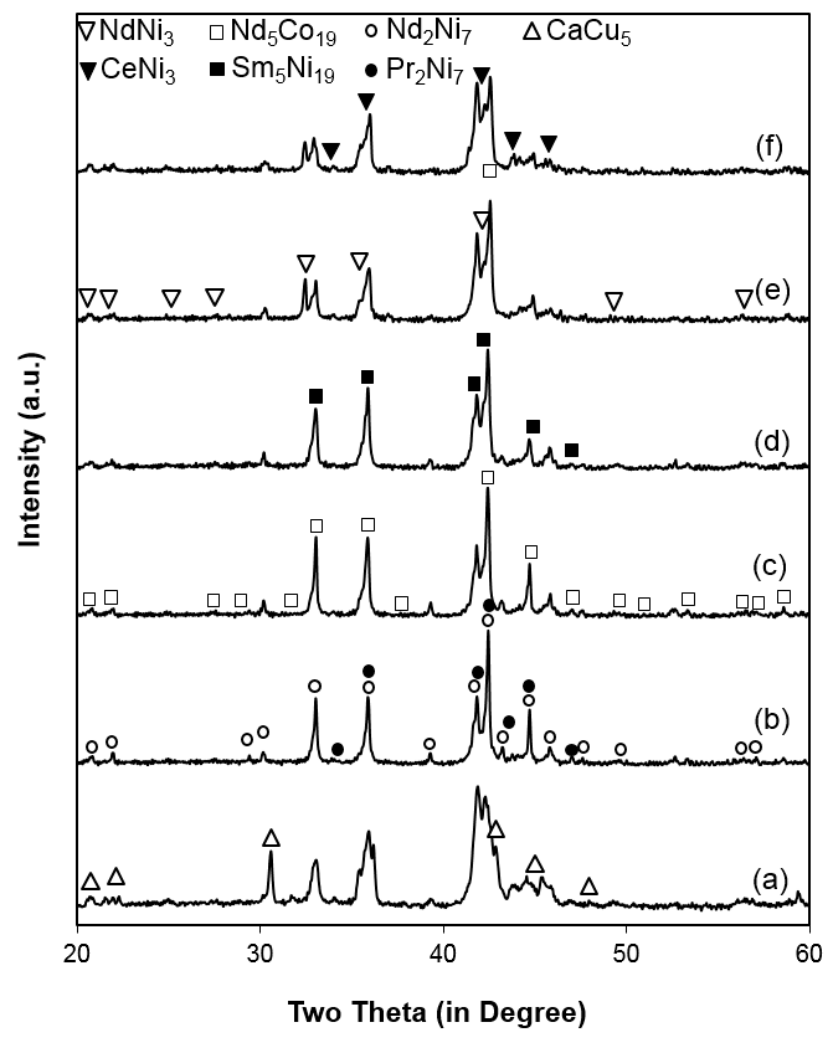

Figure 2. XRD patterns using $\mathrm{Cu}-\mathrm{K}_{\alpha}$ as the radiation source for alloys (a) A0, (b) A1, (c) A2, (d) A3, (e) A4, and (f) A5. 


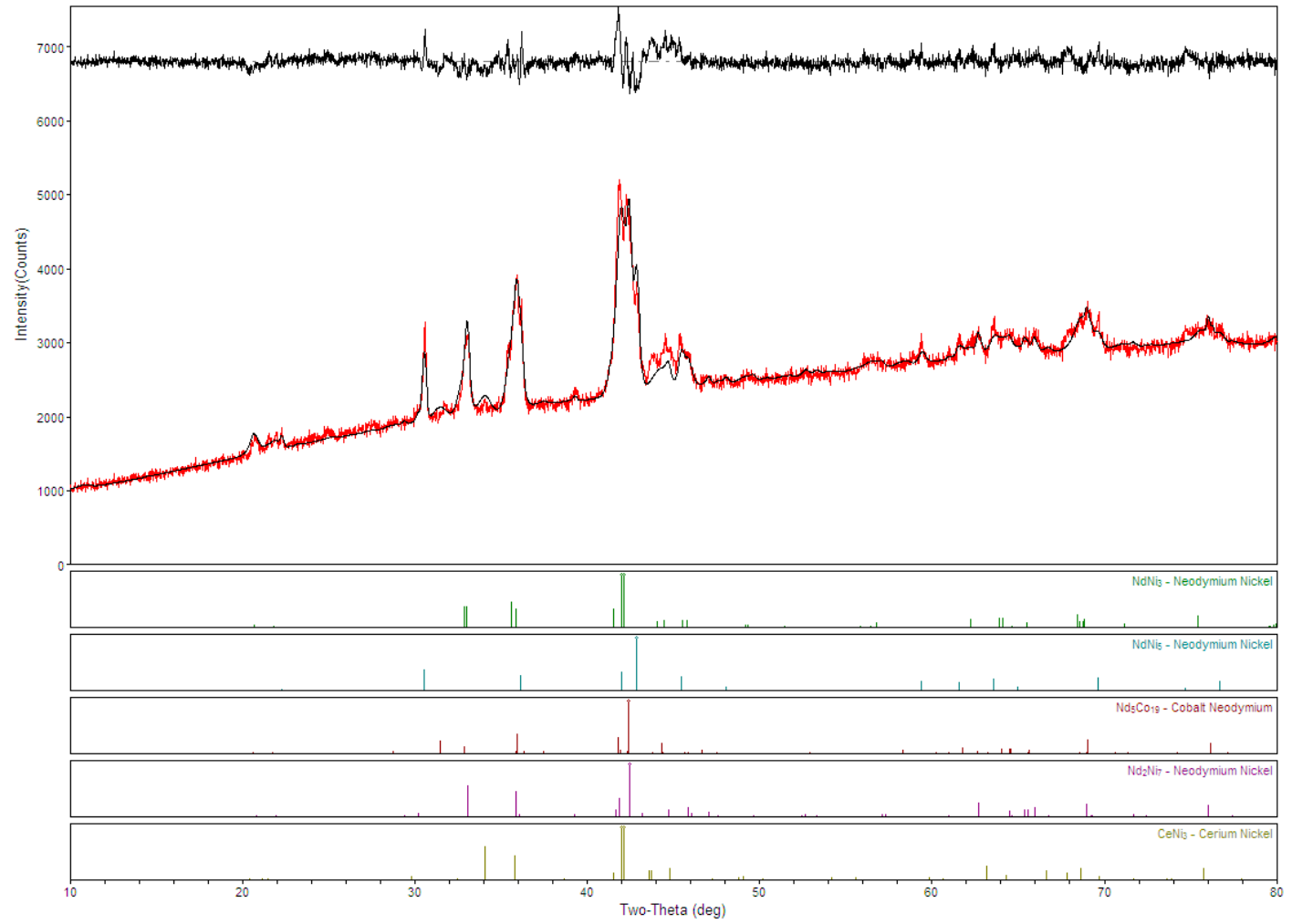

Figure 3. Phase deconvolution performed by Jade 9 software on XRD pattern from alloy A0. The red and black lines are the raw data and fitting curve, respectively. The residue of fitting is plotted in the top of the figure.

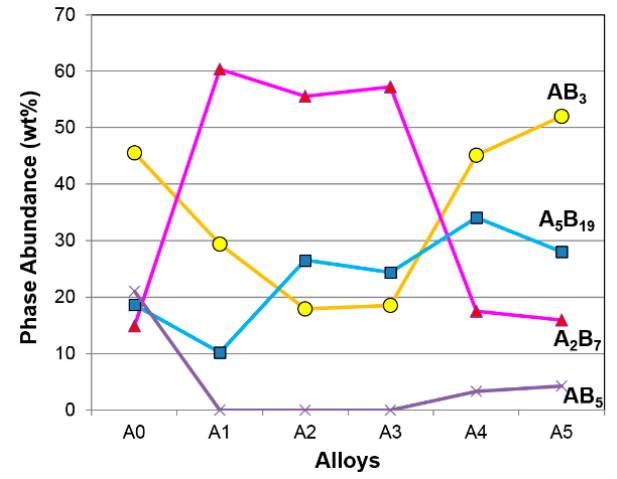

(a)

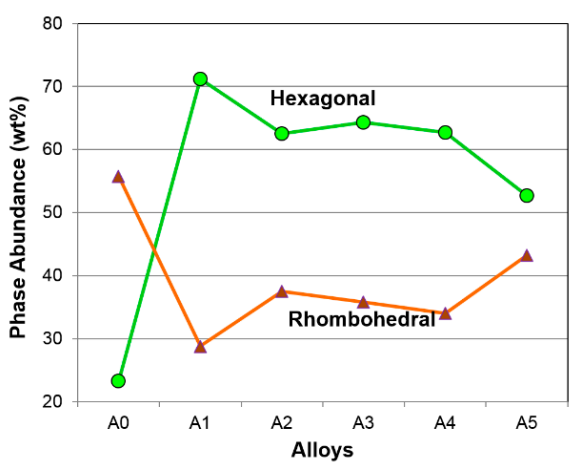

(b)

Figure 4. Phase abundance distributions classified by (a) stoichiometry and (b) structure family.

Table 2. Abundances (in wt \%) of the constituent phases obtained from the XRD data for hexagonal $(\mathrm{H})$ and rhombohedral (R) systems.

\begin{tabular}{|c|c|c|c|c|c|c|c|}
\hline Alloy & $\mathrm{CeNi}_{3}(\mathrm{H})$ & $\mathrm{NdNi}_{3}(\mathrm{R})$ & $\mathrm{Nd}_{2} \mathrm{Ni}_{7}(\mathrm{H})$ & $\mathrm{Pr}_{2} \mathrm{Ni}_{7}(\mathrm{R})$ & $\mathrm{Sm}_{5} \mathrm{Ni}_{19}(\mathrm{H})$ & $\mathrm{Nd}_{5} \mathrm{Co}_{19}(\mathrm{R})$ & $\mathrm{CaCu}_{5}(\mathrm{H})$ \\
\hline A0 & 8.4 & 37.1 & 14.9 & - & - & 18.6 & 21.0 \\
\hline A1 & 20.8 & 8.6 & 50.4 & 10.0 & - & 10.2 & - \\
\hline $\mathrm{A} 2$ & - & 17.9 & 48.6 & 7.0 & 13.9 & 12.6 & - \\
\hline $\mathrm{A} 3$ & - & 18.5 & 52.4 & 4.8 & 11.9 & 12.5 & - \\
\hline A4 & 24.3 & 20.8 & 17.5 & - & 20.9 & 13.2 & 3.3 \\
\hline A5 & 24.3 & 27.7 & 15.9 & - & 12.5 & 15.5 & 4.2 \\
\hline
\end{tabular}


Representative SEM backscattering electron image (BEI) micrographs from alloys A0 (as-cast) and A3 (annealed at $920^{\circ} \mathrm{C}$ ) are compared in Figure 5. While obvious phase segregation can be observed in alloy A0 (Figure 5a), alloy A3 appears to be more uniform (Figure 5b). EDS was used to measure chemical compositions of several spots in each micrograph, and the results are summarized in Table 3 . In alloy $\mathrm{A} 0$ (Figure 5a), undissolved $\mathrm{La}$ (spot 1), the $\mathrm{SmNi}$ (spot 2), $\mathrm{AB}_{3}$ (spot 4), $\mathrm{AB}_{2}$ (spot 6) and $\mathrm{AB}_{5}$ (spot 7) phases can be identified. The main phase (spot 5) is a mixture of the $A_{3}, A_{2} B_{7}$, and $A_{5} B_{19}$ phases. In the annealed alloy $A 3$, only occasional undissolved $\mathrm{La}$ and $\mathrm{Sm}$ (spot 1 ) and the $\mathrm{AB}_{2}$ phase (spot 4) can be identified, and the majority is composed of a fine mixture of the $A_{3}, A_{2} B_{7}$, and $A_{5} B_{17}$ phases (Figure 5b).

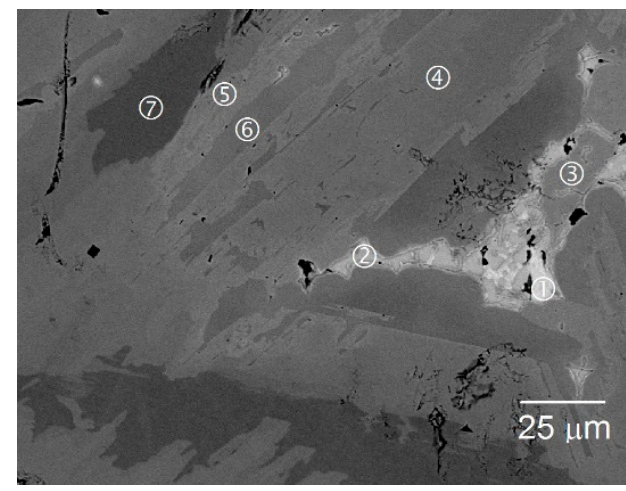

(a)

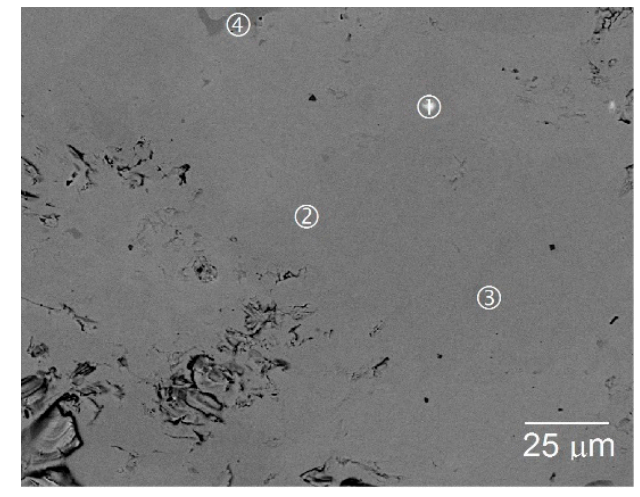

(b)

Figure 5. SEM backscattering electron image (BEI) micrographs from alloys (a) A0 and (b) A3. Compositions of the numbered areas were analyzed by EDS, and the results are shown in Table 3.

Table 3. Summary of EDS results from several selective spots in the SEM-BEI micrographs of alloys A0 and A3 shown in Figure 5a,b.

\begin{tabular}{|c|c|c|c|c|c|c|c|c|}
\hline Sample & Location & La & Sm & Mg & $\mathrm{Ni}$ & Al & B/A & Phase \\
\hline \multirow{7}{*}{ A0 } & $3 a-1$ & 90.8 & 5.1 & 1.5 & 1.9 & 0.7 & 0.03 & $\mathrm{La}$ \\
\hline & $3 a-2$ & 2.5 & 42.9 & 7.3 & 47.0 & 0.3 & 0.90 & $\mathrm{AB}$ \\
\hline & $3 a-3$ & 9.3 & 13.6 & 5.2 & 65.7 & 6.2 & 2.56 & $\mathrm{AB}_{2} / \mathrm{AB}_{3}$ \\
\hline & $3 a-4$ & 4.1 & 15.3 & 5.4 & 71.6 & 3.6 & 3.03 & $\mathrm{AB}_{3}$ \\
\hline & $3 a-5$ & 3.4 & 15.0 & 4.4 & 73.6 & 3.6 & 3.39 & $\mathrm{AB}_{3} / \mathrm{A}_{2} \mathrm{~B}_{7} / \mathrm{A}_{5} \mathrm{~B}_{19}$ \\
\hline & $3 a-6$ & 7.2 & 14.3 & 13.5 & 63.7 & 1.2 & 1.85 & $\mathrm{AB}_{2}$ \\
\hline & $3 a-7$ & 3.5 & 14.0 & 0.6 & 78.3 & 3.6 & 4.52 & $\mathrm{AB}_{5}$ \\
\hline \multirow{4}{*}{ A3 } & $3 b-1$ & 27.9 & 61.0 & 2.7 & 7.3 & 1.1 & 0.09 & $\mathrm{La} / \mathrm{Sm}$ \\
\hline & $3 b-2$ & 5.1 & 14.4 & 5.1 & 71.1 & 4.3 & 3.07 & $\mathrm{AB}_{3} / \mathrm{A}_{2} \mathrm{~B}_{7}$ \\
\hline & $3 b-3$ & 3.1 & 13.9 & 4.0 & 75.2 & 3.8 & 3.76 & $\mathrm{~A}_{2} \mathrm{~B}_{7} / \mathrm{A}_{5} \mathrm{~B}_{19}$ \\
\hline & $3 b-4$ & 4.8 & 14.5 & 15.6 & 64.0 & 1.0 & 1.86 & $\mathrm{AB}_{2}$ \\
\hline
\end{tabular}

\subsection{Gaseous Phase Hydrogen Storage}

In this study, PCT analysis was used to examine hydrogen absorption/desorption characteristics of alloys, and the isotherms measured at 30 and $45{ }^{\circ} \mathrm{C}$ are plotted in Figure 6. While no obvious plateau is observed in the isotherms of alloy A0, isotherms of the annealed alloys show well-defined plateau regions. GP H-storage properties obtained from the PCT analysis are summarized in Table 4. Both maximum and reversible capacities first increase and then decrease with an increase in annealing temperature, and the annealed alloys have higher storage capacities compared to the as-cast alloy A0. The desorption pressure at $0.75 \mathrm{wt} \% \mathrm{H}$-storage increases monotonically with an increase in annealing temperature. For the annealed alloys, the slope factor (ratio of the H-storage capacity between 0.02 and $0.5 \mathrm{MPa}$ to the total reversible capacity) first decreases (more slanted, less uniform in composition [74]) 
and then increases (flatter and more uniform in composition) as the annealing temperature increases, but all are higher than that of the as-cast alloy A0. PCT hysteresis, defined as

$$
\text { PCT hysteresis }=\ln \left(\frac{\text { absorption pressure at } 0.75 \mathrm{wt} \% \mathrm{H}-\text { storage }}{\text { desorption pressure at } 0.75 \mathrm{wt} \% \mathrm{H}-\text { storage }}\right)
$$

of alloys A4 and A5 are relatively smaller, which suggest a better resistance to pulverization during charge/discharge cycling [75]. Changes in enthalpy $(\Delta H)$ and entropy $(\Delta S)$ were calculated by using the desorption pressures $(P)$ at $0.75 \mathrm{wt} \% \mathrm{H}$-storage measured at different temperatures in the Van't Hoff equation,

$$
\Delta G=\Delta H-T \Delta S=\Re T \ln P,
$$

where $T$ and $\Re$ are the absolute temperature and ideal gas constant, respectively. Calculation results are listed in the last two rows of Table 4 . Both $\Delta H$ and $\Delta S$ of the annealed alloys are lower than those of the as-cast alloy A0. Among the annealed alloys, both $\Delta H$ and $\Delta S$ increase (except for alloy A5) with an increase in annealing temperature. The lowest $\Delta S$ value obtained from alloy $\mathrm{A} 5$ is the closest to the $\Delta S$ value for $\mathrm{H}_{2}$ gas $\left(-135 \mathrm{~J} \cdot \mathrm{mol} \mathrm{H}_{2}{ }^{-1} \mathrm{~K}^{-1}\right)$, indicating the highest degree of order of hydrogen in the MH alloy [76].

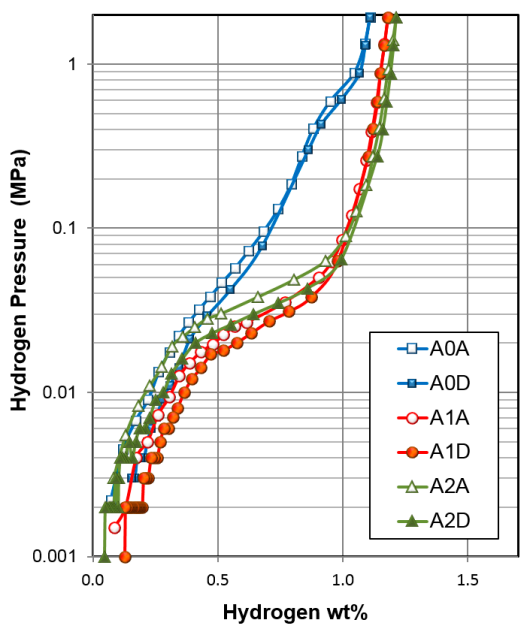

(a)

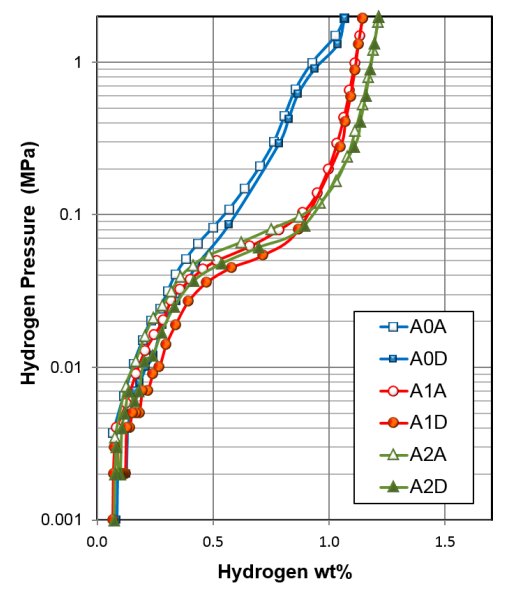

(c)

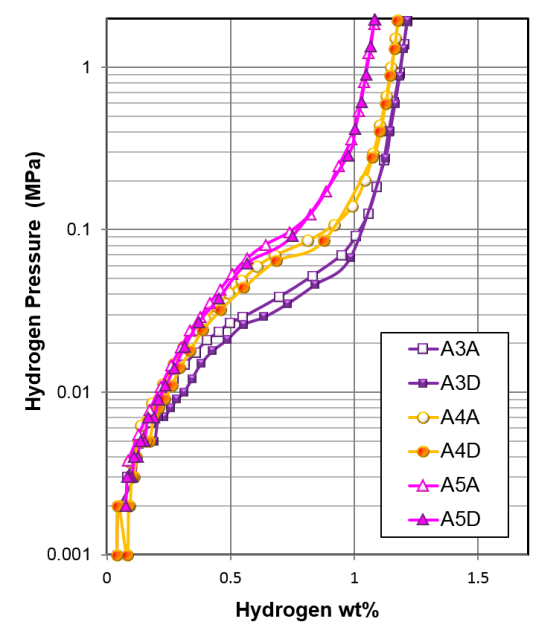

(b)

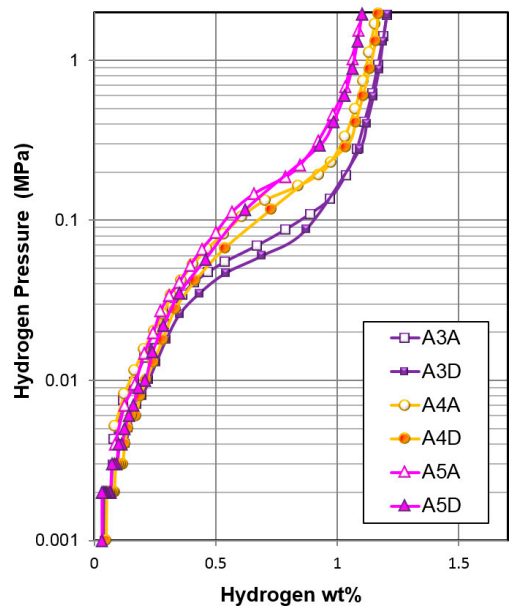

(d)

Figure 6. PCT isotherms measured at (a,b) 30 and $(\mathbf{c}, \mathbf{d}) 45^{\circ} \mathrm{C}$ for alloys A0-A5. Open and solid symbols represent absorption and desorption curves, respectively. 
Table 4. Summary of gaseous phase properties measured at $30^{\circ} \mathrm{C}$.

\begin{tabular}{lccccccc}
\hline Gaseous Phase Properties & Unit & A0 & A1 & A2 & A3 & A4 & A5 \\
\hline Capacity at 2 MPa & $\mathrm{wt} \%$ & 1.11 & 1.18 & 1.21 & 1.21 & 1.18 & 1.08 \\
Reversible capacity & $\mathrm{wt} \%$ & 0.95 & 0.98 & 1.17 & 1.17 & 1.13 & 1.00 \\
Desorption pressure & $\mathrm{MPa}$ & 0.16 & 0.029 & 0.035 & 0.037 & 0.071 & 0.091 \\
Slope factor & $\%$ & 69 & 78 & 76 & 72 & 77 & 79 \\
Hysteresis & & 0.17 & 0.16 & 0.22 & 0.17 & 0.08 & 0.09 \\
$-\Delta H$ & $\mathrm{~kJ} \cdot \mathrm{mol} \mathrm{H}_{2}^{-1}$ & 25.8 & 38.8 & 35.2 & 33.6 & 31.8 & 39.3 \\
$-\Delta S$ & $\mathrm{~J} \cdot \mathrm{mol} \mathrm{H}_{2}^{-1} \cdot \mathrm{K}^{-1}$ & 89 & 118 & 107 & 102 & 102 & 129 \\
\hline
\end{tabular}

\subsection{Electrochemical and Magnetic Susceptibility Measurements}

Before the half-cell capacity measurement, the compacted negative electrode went through a $4 \mathrm{~h}$ activation process in $30 \mathrm{wt} \% \mathrm{KOH}$ at $100^{\circ} \mathrm{C}$. The second cycle capacities obtained at different discharge currents for each alloy are plotted in Figure 7a together with those for a standard and commercially available $\mathrm{AB}_{5}$ alloy (Alloy $\mathrm{B}$ with a chemical composition of $\mathrm{La}_{10.5} \mathrm{Ce}_{4.3} \mathrm{Pr}_{0.5} \mathrm{Nd}_{1.4} \mathrm{Ni}_{60} \mathrm{Co}_{12.7} \mathrm{Mn}_{5.9} \mathrm{Al}_{4.7}$ supplied by Eutectix). Discharge capacity decreases with the increase in discharge rate in a roughly linear manner. The slope of capacity vs. discharge rate for the superlattice alloys (dashed red line) is lower than the slope for the $\mathrm{AB}_{5}$ alloy (solid green line), which confirms the superiority of superlattice alloys in HRD, as previously reported [30]. EC test results of alloys in this study are summarized in Table 5. Annealing improves the capacity substantially. Both the capacity and half-cell HRD (the ratio between the capacities obtained at 400 and $5 \mathrm{~mA} \cdot \mathrm{g}^{-1}$ ) increase first and then decrease with the increase in annealing temperature and peak at alloy A2 (Figure 7b). EC discharge capacities of alloys A1 to A3 ( 323 to $326 \mathrm{mAh} \cdot \mathrm{g}^{-1}$ ) are very close to the maximum H-storage capacities in GP (1.18 to $1.21 \mathrm{wt} \%$, which is equivalent to 316 to $324 \mathrm{mAh} \cdot \mathrm{g}^{-1}$ ).

Evolution in half-cell HRD was further investigated by the bulk hydrogen diffusion constant $(D)$ and surface reaction current $\left(I_{\mathrm{O}}\right)$, and the results are listed in Table 5. Details of both measurements were previously reported [33]. While the $D$ value remains approximately the same, the $I_{\mathrm{o}}$ value peaks at alloy A2. Therefore, we conclude the half-cell HRD in this series of annealed superlattice alloys is related more to the surface catalytic ability, which agrees with our previous findings from the Co-substituted $\mathrm{Mm}$-based superlattice $\mathrm{MH}$ alloys [33]. With the $-40{ }^{\circ} \mathrm{C}$ AC impedance measurement, both charge-transfer resistance $(R)$ and double-layer capacitance $(C)$ were obtained, and are summarized in Table 5. With an increase in annealing temperature, both $R$ and $R C$ product (a measure of surface catalytic ability [77]) first decrease and then increase; this trend is similar to that observed in HRD. Moreover, alloys A2, A3, and A4 demonstrate the best low-temperature performance (the lowest $R \mathrm{~s}$ ), which is dominated by the surface catalytic ability (the lowest $R C$ products).

Magnetic susceptibility was measured to study the evolution in surface metallic $\mathrm{Ni}$ with the annealing temperature. Details of this measurement and the connection between magnetic susceptibility and HRD were previously published $[78,79]$. Saturated magnetic susceptibility $\left(M_{\mathrm{S}}\right.$, closely related to the surface catalytic ability) first decreases and then increases with an increase in annealing temperature, suggesting that the surface's catalytic ability first decreases and then increases. This result is contradictory to the conclusion drawn from the $R C$ product result. Therefore, the lowest $R$ s and $R C$ products observed in alloys A2, A3, and A4 do not correlate with the amount of surface metallic nickel. This discrepancy is rare, but there is example when the surface oxide microstructure, rather than the metallic nickel, played an important role in affecting the HRD and low temperature performances [80]. Further study of the surface oxide microstructure by transmission microscope is necessary to explain the source of highly catalytic surface of alloys A2, A3, and A4. Lastly, the applied field strength corresponding to half of $M_{\mathrm{S}}\left(\mathrm{H}_{1 / 2}\right)$ of these alloys are similar, indicating the size of metallic nickel inclusion in the surface oxide remains constant despite the change in annealing condition. 


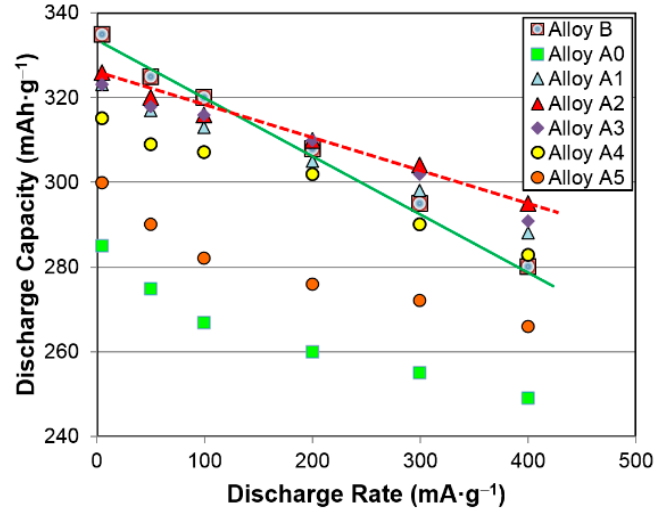

(a)

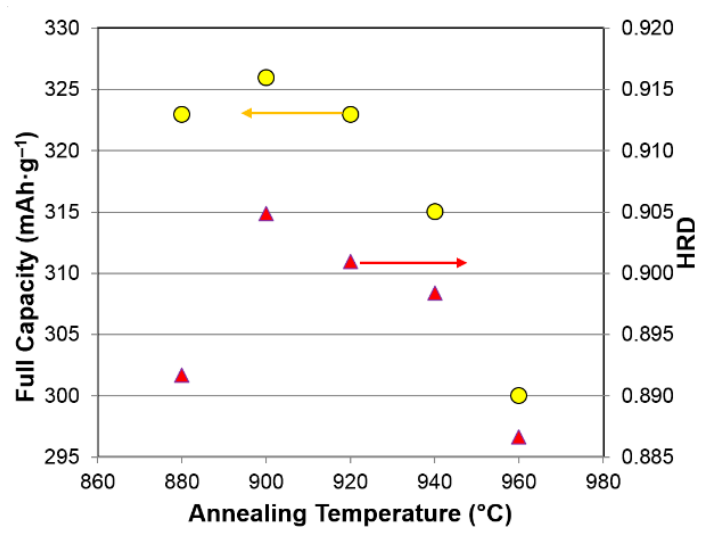

(b)

Figure 7. Electrochemical discharge capacities as functions of (a) discharge rate and (b) annealing temperature. Alloy $\mathrm{B}$ is a commercially available La-rich $\mathrm{AB}_{5} \mathrm{MH}$ alloy.

Table 5. Summary of electrochemical half-cells.

\begin{tabular}{llcccccc}
\hline Electrochemical and Magnetics Properties & \multicolumn{1}{c}{ Unit } & A0 & A1 & A2 & A3 & A4 & A5 \\
\hline High-rate discharge capacity & $\mathrm{mAh} \cdot \mathrm{g}^{-1}$ & 249 & 288 & 295 & 291 & 283 & 266 \\
Full discharge capacity & $\mathrm{mAh} \cdot \mathrm{g}^{-1}$ & 285 & 323 & 326 & 323 & 315 & 300 \\
Half-cell HRD & $\%$ & 87.5 & 89.2 & 90.4 & 90.1 & 89.8 & 88.7 \\
Diffusion coefficient, $\mathrm{D}$ & $10^{-10} \mathrm{~cm}^{2} \cdot \mathrm{s}^{-1}$ & 4.0 & 4.0 & 4.2 & 4.4 & 4.2 & 4.1 \\
Surface reaction current, $\mathrm{I}_{\mathrm{O}}$ & $\mathrm{mA} \cdot \mathrm{g}^{-1}$ & 24.2 & 24.0 & 33.1 & 23.8 & 21.9 & 17.6 \\
Charge-transfer resistance at $-40^{\circ} \mathrm{C}, R$ & $\Omega \cdot \mathrm{g}^{-1}$ & 4.9 & 8.8 & 4.0 & 3.7 & 3.4 & 5.3 \\
Double-layer capacitance at $-40^{\circ} \mathrm{C}, \mathrm{C}$ & $\mathrm{F} \cdot \mathrm{g}^{-1}$ & 1.6 & 0.86 & 1.02 & 0.88 & 1.12 & 1.29 \\
$R C$ product at $-40^{\circ} \mathrm{C}$ & $\mathrm{S}$ & 7.7 & 7.6 & 4.1 & 3.3 & 3.8 & 6.8 \\
Total saturated magnetic susceptibility, $M_{\mathrm{S}}$ & $\mathrm{emu} \cdot \mathrm{g}^{-1}$ & 1.45 & 1.36 & 0.96 & 0.60 & 1.05 & 1.12 \\
Applied field where M.S. $=\frac{1}{2} \mathrm{M}_{\mathrm{S}}, \mathrm{H}_{1 / 2}$ & $\mathrm{kOe}$ & 0.11 & 0.10 & 0.11 & 0.12 & 0.10 & 0.10 \\
\hline
\end{tabular}

\subsection{Sealed Cell Performance}

Five annealed alloys (alloys A1 to A5) were incorporated into cylindrical C-size cells (20 cells for each alloy), and each cell has a nominal capacity of 5.0 Ah. After a standard formation process [65], cells were distributed to various tests, and the results are discussed in the following sections.

\subsubsection{High-Rate Performance}

Four different discharge rates $(\mathrm{C} / 5, \mathrm{C} / 2, \mathrm{C}$, and $2 \mathrm{C})$ were used to obtain the room temperature (RT) discharge voltage curves, and the results from cells made with alloys $\mathrm{A} 1$ and $\mathrm{A} 3$ are shown in Figure 8. As the discharge rate increases, voltage is suppressed by the internal resistivity in the cell [65], and the discharge capacity obtained at the fixed cutoff voltage $(0.8 \mathrm{~V})$ decreases. Cells made with alloy A3 show a smaller voltage reduction with the increase in discharge rate, which indicates a lower cell internal resistance compared to the internal resistance in the cell made with alloy A1. The normalized discharge capacity obtained at a $2 \mathrm{C}$ rate for cells made with the five annealed alloys are listed in Table 6 . The data displays an initial increasing and later decreasing trend with an increase in alloy annealing temperature. Cells made with alloy A3 yield the best RT high-rate (2C) performance in this test. 


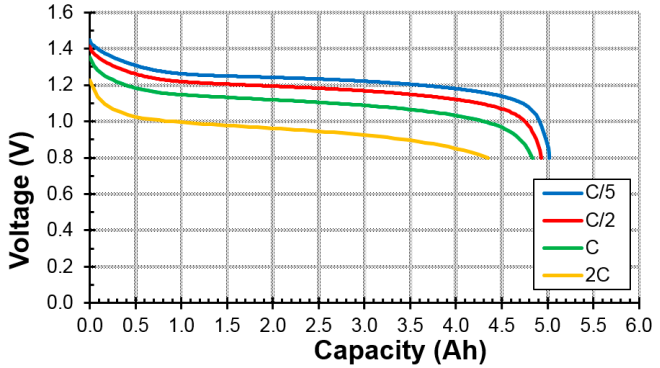

(a)

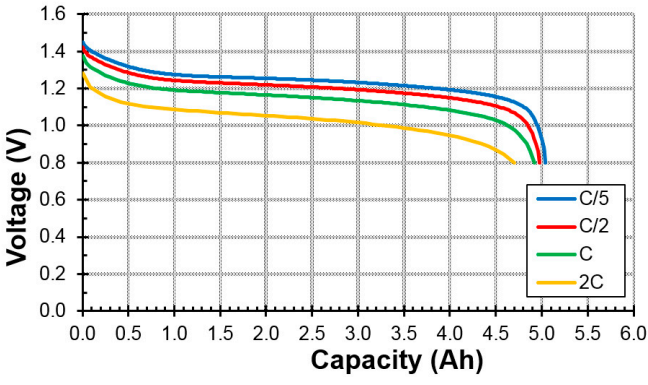

(b)

Figure 8. Room temperature discharge voltage curves at different discharge rates $(C / 5, C / 2, C$, and $2 \mathrm{C})$ for cells made with alloys (a) A1 and (b) A3.

Table 6. Summary of C-cell test results (RT stands for room temperature).

\begin{tabular}{llccccc}
\hline \multicolumn{1}{c}{ C-Cell Results } & Unit & A1 & A2 & A3 & A4 & A5 \\
\hline 2C at RT capacity/0.2C at RT capacity & $\%$ & 87 & 90 & 93 & 90 & 87 \\
1C at $-10^{\circ} \mathrm{C}$ capacity/0.2C at RT capacity & $\%$ & 92 & 94 & 95 & 94 & 91 \\
14-day charge retention & $\%$ & 85.3 & 84.9 & 84.8 & 76.1 & 85.3 \\
28-day $45^{\circ} \mathrm{C}$ voltage stand & $\mathrm{V}$ & 1.213 & 1.222 & 1.218 & 1.218 & 1.220 \\
Peak power at RT (20th cycle) & $\mathrm{W} \cdot \mathrm{kg}^{-1}$ & 183 & 198 & 206 & 200 & 194 \\
0.5C/0.5C cycle life (before reaching 3 Ah) & Number of cycles & 220 & 255 & 365 & 340 & 210 \\
C/C cycle life (before reaching 3 Ah) & Number of cycles & 110 & 185 & 205 & 130 & 120 \\
\hline
\end{tabular}

\subsubsection{Low-Temperature Performance}

Low-temperature performance was evaluated at $-10{ }^{\circ} \mathrm{C}$ and a $1 \mathrm{C}$ discharge rate, and the results are summarized in Table 6. Like the trend in high-rate performance, a trend of initial increase followed by decrease is observed for the low-temperature performance with an increase in alloy annealing temperature. The cell made with alloy $\mathrm{A} 3$ shows the best low-temperature result, which can be attributed to its surface catalytic ability being the best (lowest $R C$ product in Table 5).

\subsubsection{Charge Retention}

RT charge retention test results are shown in Figure 9a. All cells (except for the one made with alloy A4) exhibit similar charge retention characteristics. Three cells made with alloy A4 were tested, and all show inferior charge retention performance compared to the cells made with the other annealed alloys. $45^{\circ} \mathrm{C}$ voltage stand test results are plotted in Figure $9 \mathrm{~b}$ and summarized in Table 6 . In this test, the cells made with alloy A2 demonstrate the best result.

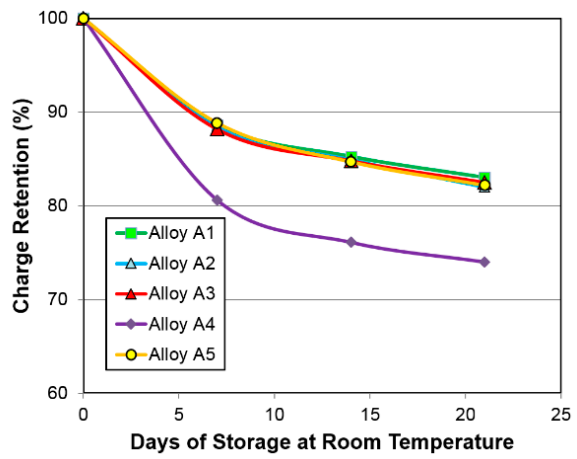

(a)

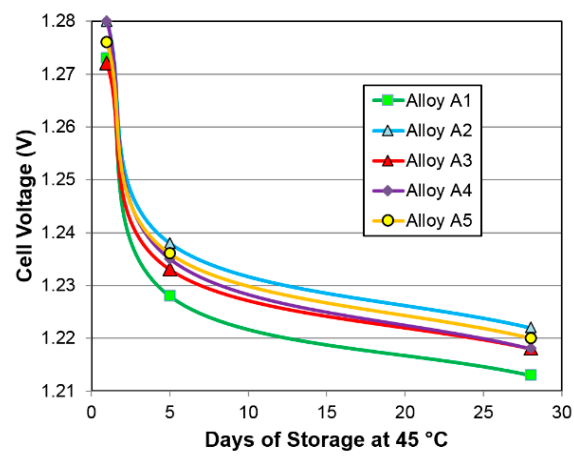

(b)

Figure 9. (a) Room temperature charge retentions and (b) $45^{\circ} \mathrm{C}$ voltage stands for cells made with alloys A1 to A5. 


\subsubsection{Peak Power}

Peak power was measured at the 20th cycle and RT, and the results are compared in Table 6. Peak power follows the same trend as those in high-rate and low-temperature performances. Cells made with alloy A3 show the best balance among peak power, best high-rate, and low-temperature performances.

\subsubsection{Cycle Life}

The RT cycle life performance was evaluated in two different configurations: a regular configuration charged at a C/2 rate and discharged at a C/2 rate, and an accelerated configuration charged at a $C$ rate and discharged at a $C$ rate. The results are plotted in Figure 10 and summarized in Table 6. The number of cycles before reaching a capacity of 3 Ah first increases and then decreases with an increase in alloy annealing temperature. Cells with alloy A3 show the best cycle stability in both C/2-C/2 and C-C cycling tests. As reported previously, the main degradation mechanism for superlattice alloy free of $\mathrm{Mn}$ and $\mathrm{Co}$ is the combination of particle pulverization and surface oxidation $[34,35]$.

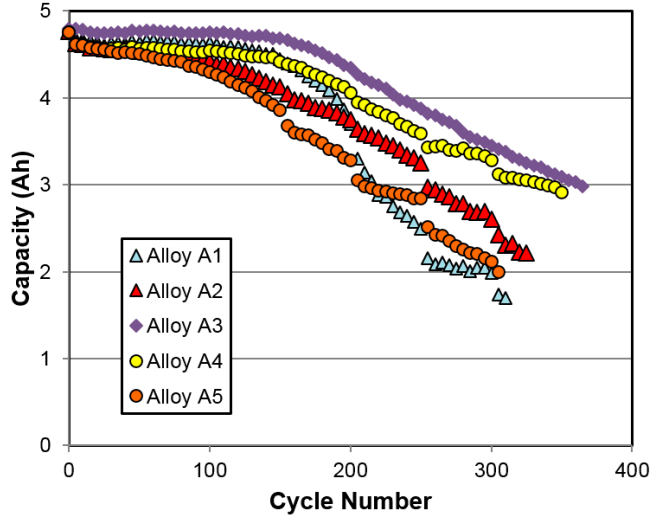

(a)

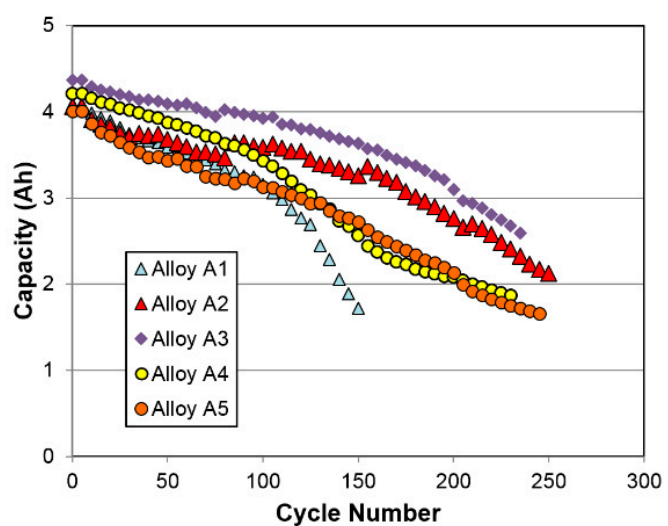

(b)

Figure 10. Room temperature cycle life from cells made with alloys A1 to A5 (a) in the configuration of a $C / 2$ rate charge, a $C / 2$ rate discharge, and a $-\Delta V$ cutoff voltage of $3 \mathrm{mV}$ and (b) in the configuration of a $C$ rate charge, a $C$ rate discharge, and a $-\Delta V$ cutoff voltage of $5 \mathrm{mV}$.

\subsection{Performance Correlation with Individual Phase}

Correlations between the seven constituent phase abundances $\left(\mathrm{CeNi}_{3}, \mathrm{NdNi}_{3}, \mathrm{Nd}_{2} \mathrm{Ni}_{7}, \mathrm{Pr}_{2} \mathrm{Ni}_{7}\right.$, $\mathrm{Sm}_{5} \mathrm{Ni}_{19}, \mathrm{Nd}_{5} \mathrm{Co}_{19}$, and $\mathrm{CaCu}_{5}$ ) and seven $\mathrm{GP}$, eight half-cell $\mathrm{EC}$, and five sealed cell properties were studied by the linear regression method, and the resulting correlation factors $\left(R^{2}\right)$ are summarized in Table 7. Although these phase abundances were obtained from the XRD analysis of the un-activated alloys, the XRD performed on the activated alloys only showed additional minute rare-earth oxide (hydride) peaks and no changes in the main phase peaks were found [81]. For the maximum H-storage capacity, $\mathrm{Nd}_{2} \mathrm{Ni}_{7}$ (Figure $11 \mathrm{a}$ ) and $\mathrm{Pr}_{2} \mathrm{Ni}_{7}$ are considered beneficial, whereas $\mathrm{NdNi}_{3}$ and $\mathrm{Nd}_{5} \mathrm{Co}_{19}$ are detrimental. Reversible $\mathrm{H}$-storage capacity does not correlate well with any phase. $\mathrm{NdNi}_{3}, \mathrm{Nd}_{5} \mathrm{Co}_{19}$ (Figure 11b), and $\mathrm{CaCu}_{5}$ (Figure 11c) are effective in increasing the PCT plateau pressure; however, $\mathrm{Nd}_{2} \mathrm{Ni}_{7}$ and $\mathrm{Pr}_{2} \mathrm{Ni}_{7}$ have an opposite effect. CeNi 3 increases the flatness of PCT isotherm, but $\mathrm{CaCu}_{5}$ decreases it. While $\mathrm{CeNi}_{3}$ reduces the PCT hysteresis, $\mathrm{Nd}_{2} \mathrm{Ni}_{7}$ and $\mathrm{Pr}_{2} \mathrm{Ni}_{7}$ increase it (Figure $11 \mathrm{~d}$ ). The only strong influence on the change in enthalpy is from $\mathrm{CaCu}_{5}$, which contributes to a much less negative $\Delta H$ value (weaker metal-hydrogen bond strength). $\mathrm{NdNi}_{3}$ and $\mathrm{Nd}_{5} \mathrm{Co}_{19}$ may also increase $\Delta H$. None of the phases have a significant correlation with the change in entropy (which is essentially the change of entropy between hydrogen gas and hydrogen in an ordered solid). 


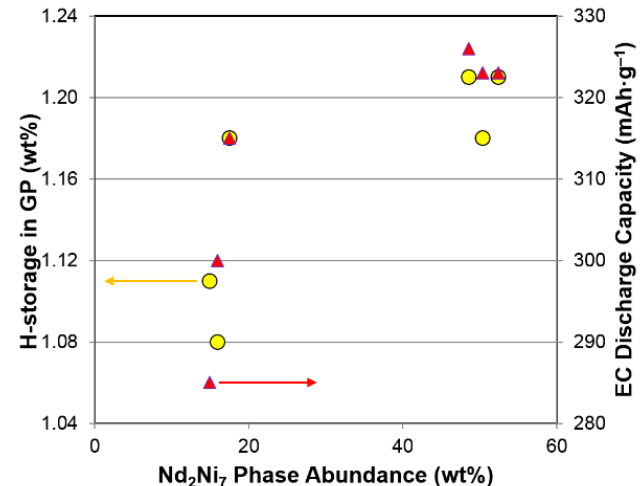

(a)

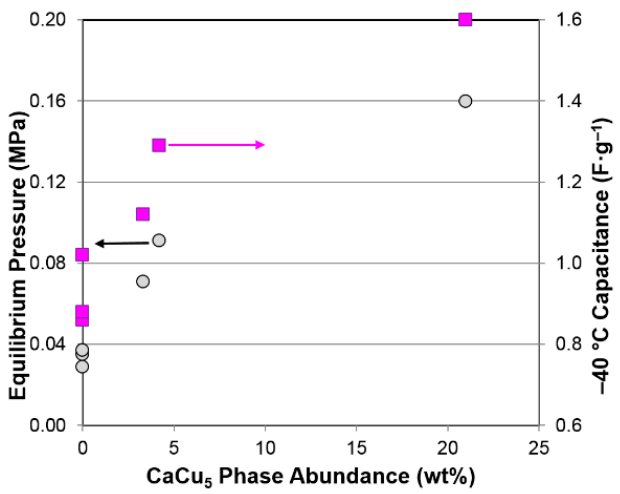

(c)

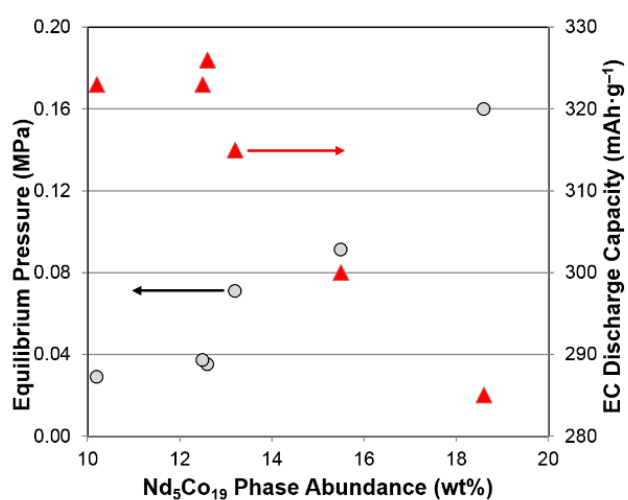

(b)

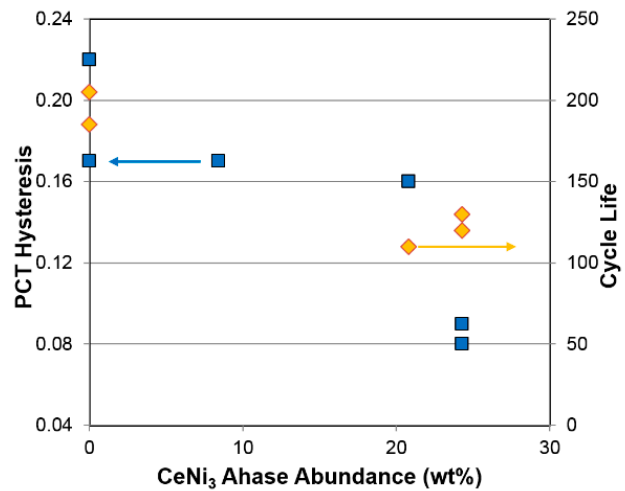

(d)

Figure 11. Examples of correlations between the constituent phase abundances and several gaseous phase/electrochemical properties: (a) $\mathrm{Nd}_{2} \mathrm{Ni}_{7}$ (b) $\mathrm{Nd}_{5} \mathrm{Co}_{19}$ (c) $\mathrm{CaCu}_{5}$ (d) $\mathrm{CeNi}_{3}$.

Table 7. Correlation factors $\left(R^{2}\right)$ between the constituent phase abundances and various gaseous phase, half-cell, and sealed cell properties. Plus (+) and minus ( - ) signs after the numbers indicate positive and negative correlations, respectively. Significant correlations with $R^{2} \geq 0.6$ are highlighted in red. EC full capacity is the discharge capacity measured with a $5 \mathrm{~mA} \cdot \mathrm{g}^{-1}$ current density.

\begin{tabular}{lccccccc}
\hline \multicolumn{1}{c}{ Properties } & $\mathbf{C e N i}_{\mathbf{3}}$ & $\mathbf{N d N i}_{\mathbf{3}}$ & $\mathbf{N d}_{\mathbf{2}} \mathbf{N i}_{\mathbf{7}}$ & $\mathbf{P r}_{\mathbf{2}} \mathbf{N i}_{\mathbf{7}}$ & $\mathbf{S m}_{\mathbf{5}} \mathbf{N i}_{\mathbf{1 9}}$ & $\mathbf{N d}_{\mathbf{5}} \mathbf{C o}_{\mathbf{1 9}}$ & $\mathbf{C a C u}_{\mathbf{5}}$ \\
\hline GP maximum capacity & $0.26-$ & $0.51-$ & $0.63+$ & $0.42+$ & $0.07+$ & $0.55-$ & $0.38-$ \\
GP reversible capacity & $0.24-$ & $0.14-$ & $0.21+$ & $0.03+$ & $0.57+$ & $0.20-$ & $0.37-$ \\
Equilibrium pressure & $0.02+$ & $0.89+$ & $0.68-$ & $0.58-$ & $0.09-$ & $0.92+$ & $0.92+$ \\
PCT slope factor & $0.42+$ & $0.31-$ & 0.00 & $0.05+$ & $0.14+$ & $0.31-$ & $0.46-$ \\
PCT hysteresis & $0.73-$ & $0.03-$ & $0.46+$ & $0.39+$ & $0.17-$ & $0.02-$ & 0.00 \\
$\Delta H$ & $0.12-$ & $0.43+$ & $0.16-$ & $0.24-$ & $0.02-$ & $0.42+$ & $0.61+$ \\
$\Delta S$ & $0.28-$ & $0.16+$ & $0.01-$ & $0.05-$ & $0.01-$ & $0.15+$ & $0.33+$ \\
EC high-rate capacity & $0.06-$ & $0.79-$ & $0.65+$ & $0.49+$ & $0.17+$ & $0.84-$ & $0.84-$ \\
EC full capacity & $0.05-$ & $0.84-$ & $0.69+$ & $0.56+$ & $0.13+$ & $0.89-$ & $0.84-$ \\
HRD & $0.09-$ & $0.52-$ & $0.43+$ & $0.22+$ & $0.42+$ & $0.59-$ & $0.76-$ \\
Diffusion constant, $D$ & $0.25-$ & $0.05-$ & $0.16+$ & 0.00 & $0.42+$ & $0.09-$ & $0.27-$ \\
Exchange Current, $I_{\mathrm{O}}$ & $0.52-$ & $0.08-$ & $0.33+$ & $0.31+$ & 0.00 & $0.07-$ & $0.02-$ \\
$-40{ }^{\circ}$ C resistivity, $R$ & $0.15+$ & $0.17-$ & $0.06+$ & $0.32+$ & $0.53-$ & $0.11-$ & $0.01-$ \\
$-40{ }^{\circ}$ C capacitance, $C$ & $0.02+$ & $0.91+$ & $0.71-$ & $0.59-$ & $0.05+$ & $0.94+$ & $0.85+$ \\
$R C$ product & $0.17+$ & $0.08+$ & $0.11-$ & 0.00 & $0.65-$ & $0.13+$ & $0.29+$ \\
High rate & $0.54-$ & 0.00 & $0.14+$ & 0.00 & $0.20+$ & 0.00 & $0.15-$ \\
Low temperature & $0.50-$ & $0.02-$ & $0.18+$ & $0.01+$ & $0.19+$ & $0.07-$ & $0.23-$ \\
Charge retention & $0.17-$ & $0.03-$ & $0.31+$ & $0.30+$ & $0.48-$ & $0.01-$ & $0.21-$ \\
Peak power & $0.29-$ & $0.25+$ & 0.00 & $0.23-$ & $0.56+$ & $0.17+$ & 0.00 \\
Cycle life & $0.90-$ & 0.00 & $0.31+$ & $0.02+$ & $0.07+$ & 0.00 & $0.30-$ \\
\hline
\end{tabular}


For the EC properties, $\mathrm{Nd}_{2} \mathrm{Ni}_{7}$ (Figure 11a) and $\mathrm{Pr}_{2} \mathrm{Ni}_{7}$ make positive contributions to the high-rate and low-rate discharge capacities, while $\mathrm{NdNi}_{3}, \mathrm{Nd}_{5} \mathrm{Co}_{19}$ (Figure 11b) and $\mathrm{CaCu}_{5}$ have an opposite effect. $\mathrm{Nd}_{2} \mathrm{Ni}_{7}$ and $\mathrm{Sm}_{5} \mathrm{Ni}_{19}$ increase $\mathrm{HRD}$, but $\mathrm{NdNi}_{3}, \mathrm{Nd}_{5} \mathrm{Co}_{19}$, and $\mathrm{CaCu}_{5}$ decrease it. The increase in HRD comes from different sources: improvement in surface reaction for $\mathrm{Nd}_{2} \mathrm{Ni}_{7}$ (indicated by its positive correlation with $I_{\mathrm{o}}$ ) and enhancement of bulk diffusion for $\mathrm{Sm}_{5} \mathrm{Ni}_{19}$ (indicated by its positive correlation with $D$ ). For the low-temperature characteristics determined by the AC impedance measured at $-40{ }^{\circ} \mathrm{C}, \mathrm{Sm}_{5} \mathrm{Ni}_{19}$ decreases the charge-transfer resistance by increasing the surface's catalytic ability (indicated by its negative correlation with the $R C$ product), but $\mathrm{Pr}_{2} \mathrm{Ni}_{7}$ increases it by reducing the surface's reactive area (indicated by its negative correlation with $C$ ). Although $\mathrm{NdNi}_{3}$, $\mathrm{Nd}_{5} \mathrm{Co}_{19}$, and $\mathrm{CaCu}_{5}$ (Figure 11c) can increase the surface reactive area, they have a marginal effect on the charge-transfer resistance, due to their relatively low catalytic abilities.

Judging from the ratio between the number of significant correlations $\left(R^{2} \geq 0.60\right)$ found and number of properties ( $7 / 7$ for the GP properties, $14 / 8$ for the half-cell EC properties, and 2/5 for the sealed cell properties), correlations with the sealed cell properties are the weakest. There are two explanations for the difficulty in setting up correlations for the sealed cell properties: manual assembly operation and limited cell number. While the former adds inconsistency, the latter limits the accuracy of sampling. Therefore, further confirmation on a larger scale (hundreds of cells) is needed. Nevertheless, correlations obtained from the 100 cells (20 for each annealed alloy) in this study are shown in the bottom five rows of Table 7. Only $\mathrm{CeNi}_{3}$ shows a significant and detrimental effect on the high-rate performance. For the low-temperature performance, only $\mathrm{Sm}_{5} \mathrm{Ni}_{19}$ exhibits a positive influence. Both $\mathrm{Nd}_{2} \mathrm{Ni}_{7}$ and $\mathrm{Pr}_{2} \mathrm{Ni}_{7}$ show a positive impact on the charge retention performance, but $\mathrm{Sm}_{5} \mathrm{Ni}_{19}$ influences it negatively. Among all phases, $\mathrm{Sm}_{5} \mathrm{Ni}_{19}$ most effectively increases the peak power. Only $\mathrm{NdNi}_{3}$ contributes to the increase in cycle stability, whereas $\mathrm{CeNi}_{3}$ (Figure 11d) and $\mathrm{CaCu}_{5}$ deteriorate it.

As the exact chemical composition in each superlattice phase cannot be quantified by SEM-EDS, the correlations found in this session may come from the non-uniform distribution of A-site and B-site elements in these phases, but this cannot be verified.

\subsection{Performance Correlation with Phase Stoichiometry}

In earlier superlattice $\mathrm{MH}$ alloy studies of various phases' contributions to the EC performances, phases are grouped according to the phase stoichiometry, such as $\mathrm{AB}_{3}\left(\mathrm{CeNi}_{3}\right.$ and $\left.\mathrm{NdNi}_{3}\right), \mathrm{A}_{2} \mathrm{~B}_{7}$ $\left(\mathrm{Nd}_{2} \mathrm{Ni}_{7}\right.$ and $\left.\mathrm{Pr}_{2} \mathrm{Ni}_{7}\right)$, and $\mathrm{A}_{5} \mathrm{~B}_{19}\left(\mathrm{Sm}_{5} \mathrm{Ni}_{19}\right.$ and $\left.\mathrm{Nd}_{5} \mathrm{Co}_{19}\right)$ [28-30]. In this study, we correlated the properties with the phase stoichiometry, and the resulted $R^{2} \mathrm{~s}$ are summarized and shown in the first three columns of Table 8. $\mathrm{AB}_{3}$ decreases the GP and EC capacities (Figure 12a), increases the plateau pressure, decreases HRD because of the reductions in $D$ and $I_{0}$, which also contribute to an inferior high-rate performance. Moreover, although $\mathrm{AB}_{3}$ decreases the PCT hysteresis, it still deteriorates the cycle stability. $A_{2} B_{7}$ increases the GP and EC capacities (Figure 12b), lowers the equilibrium pressure, increases HRD because of the enhanced $D$ and $I_{0}$, and improves both the charge retention and cycle life. $\mathrm{A}_{5} \mathrm{~B}_{19}$ increases the GP reversible $\mathrm{H}$-storage, improves the $-40{ }^{\circ} \mathrm{C}$ performance via the increase in surface catalytic ability, increases the peak power, and deteriorates the charge retention. By comparing these correlations, $\mathrm{A}_{2} \mathrm{~B}_{7}$ appears to be the most desirable stoichiometry for battery applications among all stoichiometries for the superlattice $\mathrm{MH}$ alloys. This conclusion is in complete agreement with previous reports [29-31]. 


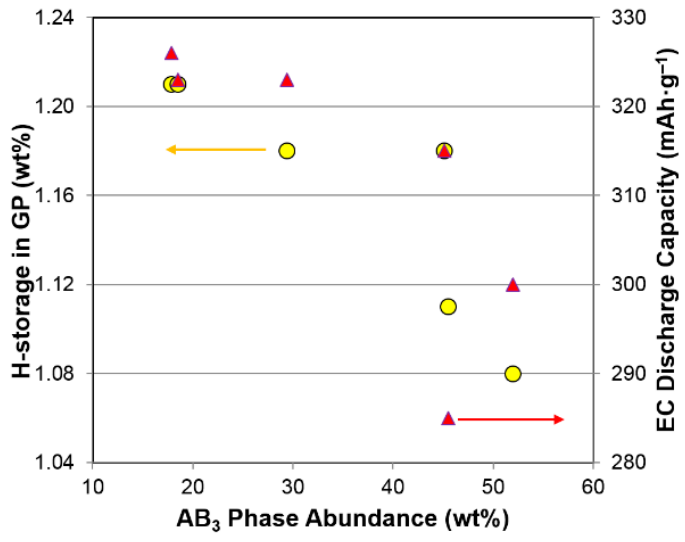

(a)

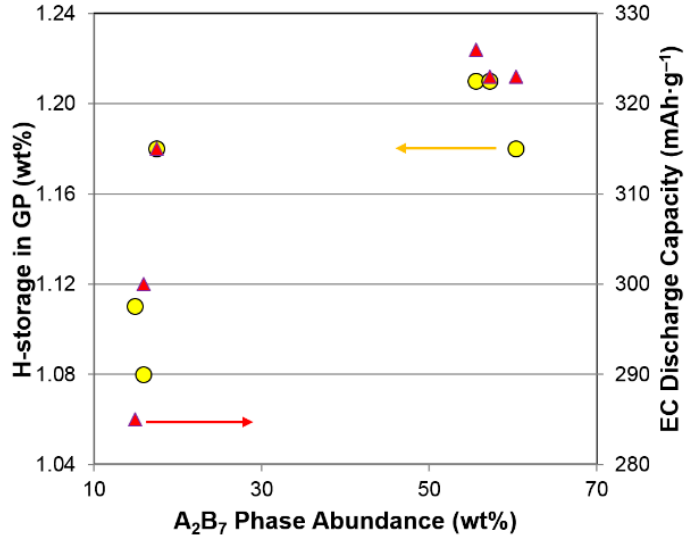

(b)

Figure 12. Examples of correlations between the abundances of phases with (a) an $\mathrm{AB}_{3}$ and (b) an $\mathrm{A}_{2} \mathrm{~B}_{7}$ stoichiometry and several gaseous phase/electrochemical properties.

Table 8. Correlation factors $\left(R^{2}\right)$ between the phase stoichiometry/structure and various gaseous phase, half-cell, and sealed cell properties and. Plus $(+)$ and minus $(-)$ signs after the numbers indicate positive and negative correlations, respectively. Significant correlations with $R^{2} \geq 0.6$ are highlighted in red. EC full capacity is the discharge capacity measured with a $5 \mathrm{~mA} \cdot \mathrm{g}^{-1}$ current density.

\begin{tabular}{lccccc}
\hline \multicolumn{1}{c}{ Properties } & $\mathbf{A B}_{\mathbf{3}}$ & $\mathbf{A}_{\mathbf{2}} \mathbf{B}_{\mathbf{7}}$ & $\mathbf{A}_{\mathbf{5}} \mathbf{B}_{\mathbf{1 9}}$ & Hexagonal & Rhombohedral \\
\hline GP maximum capacity & $0.75-$ & $0.60+$ & 0.00 & $0.44+$ & $0.46-$ \\
GP reversible capacity & $0.40-$ & $0.17+$ & $0.36+$ & $0.29+$ & $0.21-$ \\
Equilibrium pressure & $0.52+$ & $0.68-$ & 0.00 & $0.93-$ & $0.85+$ \\
PCT slope factor & $0.02+$ & $0.01+$ & $0.03+$ & $0.45+$ & $0.41-$ \\
PCT hysteresis & $0.61-$ & $0.46+$ & $0.21-$ & 0.00 & 0.00 \\
$\Delta H$ & $0.03+$ & $0.17-$ & $0.01+$ & $0.54-$ & $0.43+$ \\
$\Delta S$ & $0.02-$ & $0.01-$ & 0.00 & $0.26-$ & $0.18+$ \\
EC high-rate capacity & $0.60-$ & $0.63+$ & $0.01+$ & $0.84+$ & $0.78-$ \\
EC full capacity & $0.61-$ & $0.68+$ & 0.00 & $0.86+$ & $0.81-$ \\
HRD & $0.49-$ & $0.40+$ & $0.14+$ & $0.70+$ & $0.59-$ \\
Diffusion constant, $D$ & $0.29-$ & $0.11+$ & $0.29+$ & $0.18+$ & $0.11-$ \\
Exchange Current, $I_{\mathrm{O}}$ & $0.56-$ & $0.34+$ & $0.01-$ & $0.02+$ & $0.01-$ \\
$-40^{\circ} \mathrm{C}$ resistivity, $R$ & 0.00 & $0.10+$ & $0.72-$ & $0.04+$ & $0.08-$ \\
$-40{ }^{\circ}$ C capacitance, $C$ & $0.53+$ & $0.71-$ & $0.01+$ & $0.90-$ & $0.88+$ \\
$R C$ product & $0.26+$ & $0.08-$ & $0.46-$ & $0.23-$ & $0.16+$ \\
High rate & $0.34-$ & $0.09+$ & $0.13+$ & $0.02+$ & 0.00 \\
Low temperature & $0.42-$ & $0.13+$ & $0.10+$ & $0.11+$ & $0.09-$ \\
Charge retention & $0.17-$ & $0.32+$ & $0.38-$ & 0.00 & $0.04+$ \\
Peak power & $0.05-$ & $0.02-$ & $0.53+$ & $0.11-$ & $0.16+$ \\
Cycle life & $0.58-$ & $0.24+$ & $0.05+$ & 0.00 & $0.03+$ \\
\hline
\end{tabular}

\subsection{Performance Correlation with Phase Structure}

Another way to classify the various phases in the superlattice $\mathrm{MH}$ alloys is by structure symmetry. Stacking of the $\mathrm{A}_{2} \mathrm{~B}_{4}$ slabs in the $\mathrm{CeNi}_{3}, \mathrm{Nd}_{2} \mathrm{Ni}_{7}$, and $\mathrm{Sm}_{5} \mathrm{Ni}_{19}$ phases is the same as that in the $\mathrm{C} 14$ crystal structure and is considered as the hexagonal group, and the rhombohedral group containing the $\mathrm{NdNi}_{3}, \mathrm{Pr}_{2} \mathrm{Ni}_{7}$, and $\mathrm{Nd}_{5} \mathrm{Co}_{19}$ phases shares the same $\mathrm{A}_{2} \mathrm{~B}_{4}$ stacking as the $\mathrm{C} 15$ structure. The $\mathrm{C} 14$ - and C15-based $\mathrm{MH}$ alloys behave differently in the EC environment, and we have reported the comparison previously [82] and concluded that the C14-predominated alloy is more suitable for high-capacity and long-cycle life applications, whereas the $\mathrm{C} 15$-predominated alloy is preferable in applications requiring easy activation and good high-rate and low-temperature performances. Therefore, it will be interesting to determine whether similar conclusions can be drawn from the superlattice $\mathrm{MH}$ alloy study. 
$R^{2} \mathrm{~S}$ obtained by correlating the total abundances of the hexagonal and rhombohedral phase groups with various properties are listed in the last two columns in Table 8. Compared to those in the rhombohedral group, the hexagonal group shows higher GP and EC capacities (Figure 13a), a lower equilibrium pressure (Figure 13a), a flatter PCT isotherm, a better HRD (Figure 13b), and a reduced surface reactive area at $-40{ }^{\circ} \mathrm{C}$ (Figure 13b), but without affecting the charge-transfer resistance. Based on the results, a hexagonal phase will be more desirable for battery applications. Furthermore, combining the preferences in stoichiometry and structure yields the champion of this study-the $\mathrm{Nd}_{2} \mathrm{Ni}_{7}$ phase.

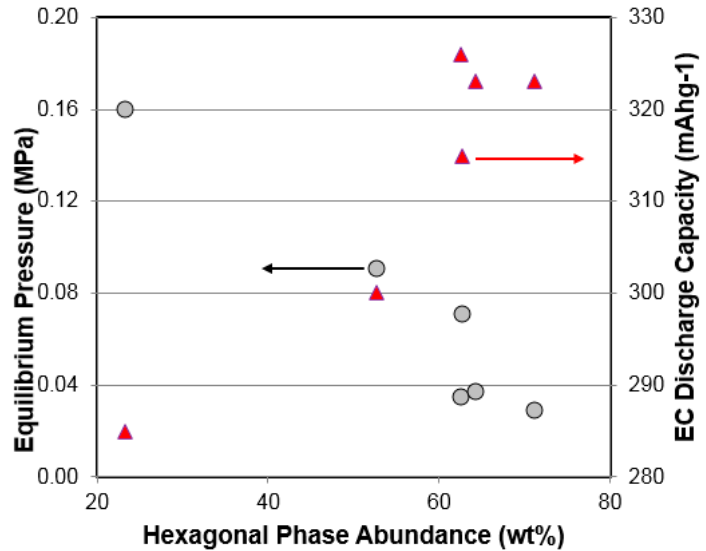

(a)

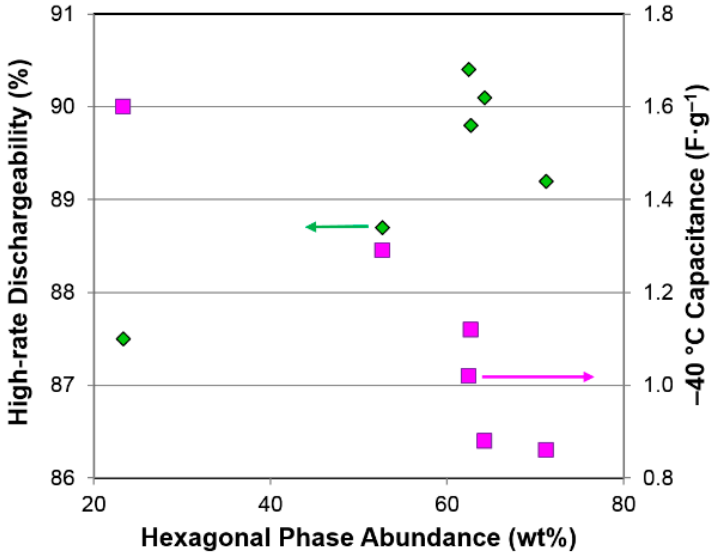

(b)

Figure 13. Plots of (a) PCT $\mathrm{H}_{2}$ equilibrium pressure and half-cell electrochemical discharge capacity and (b) half-cell high-rate dischargeability and capacitance measured at $-40{ }^{\circ} \mathrm{C}$ vs. the hexagonal superlattice structure abundance.

\section{Conclusions}

Constituent phase abundances of an SmLa-based superlattice alloy were engineered by changing the annealing temperature. Various gaseous phase, half-cell electrochemical, and sealed cell properties and performances were correlated to the individual phase, phase stoichiometry, and type of structure. Many significant correlations were identified; however, because of the complication of phase structure and limited sampling size used in this study, all correlations need further confirmation. In general, an $\mathrm{A}_{2} \mathrm{~B}_{7}$ stoichiometry and a hexagonal structure are more favorable for battery applications. Among the six superlattice phases in this study, $\mathrm{Nd}_{2} \mathrm{Ni}_{7}$ is the most desirable. As a result, establishment of a single target of maximizing $\mathrm{Nd}_{2} \mathrm{Ni}_{7}$ phase abundance simplifies the composition/process optimization task. In this study, an annealing condition of $920{ }^{\circ} \mathrm{C}$ for $5 \mathrm{~h}$ for the superlattice $\mathrm{Sm}_{14} \mathrm{La}_{5.7} \mathrm{Mg}_{4.0} \mathrm{Ni}_{73} \mathrm{Al}_{3.3} \mathrm{MH}$ alloy renders the highest $\mathrm{Nd}_{2} \mathrm{Ni}_{7}$ phase abundance and the best overall electrochemical performance.

Acknowledgments: The authors would like to thank the following individuals from BASF-Ovonic for their help: Su Cronogue, Baoquan Huang, Diana F. Wong, S. Chang, Chaolan Hu, Benjamin Reichman, Nathan English, Sui-ling Chen, Cheryl Setterington, David Pawlik, Allen Chan, and Ryan J. Blankenship.

Author Contributions: Kwo-Hsiung Young designed the experiments and analyzed the results. Taihei Ouchi prepared the alloy samples and performed the PCT and XRD analyses. Jean Nei prepared the electrode samples and conducted the magnetic measurements. Yu-Ling Lien organized the data and prepared the manuscript.

Conflicts of Interest: The authors declare no conflict of interest. 


\section{Abbreviations}

$\begin{array}{ll}\text { Mm } & \text { Misch metal } \\ \mathrm{MH} & \text { Metal hydride alloy } \\ \mathrm{Ni} / \mathrm{MH} & \text { Nickel/metal hydride } \\ \mathrm{H} \text {-storage } & \text { Hydrogen-storage } \\ \mathrm{HRD} & \text { High-rate dischargeability } \\ \mathrm{GP} & \text { Gaseous phase } \\ \mathrm{RE} & \text { Rare earth } \\ \mathrm{EC} & \text { Electrochemical } \\ \text { bcc } & \text { Body-centered-cubic } \\ \mathrm{ICP}-\mathrm{OES} & \text { Inductively coupled plasma-optical emission spectrometer } \\ \text { XRD } & \text { X-ray diffractometer } \\ \mathrm{SEM} & \text { Scanning electron microscope } \\ \mathrm{EDS} & \text { Energy dispersive spectroscopy } \\ \mathrm{PCT} & \text { Pressure-concentration-temperature } \\ \mathrm{BEI} & \text { Backscattering electron image } \\ \Delta H & \text { Change in enthalpy or heat of hydride formation } \\ \Delta S & \text { Change in entropy } \\ P & \text { Desorption pressure } \\ T & \text { Temperature } \\ R & \text { Ideal gas constant } \\ D & \text { Bulk hydrogen diffusion coefficient } \\ I_{\mathrm{O}} & \text { Surface exchange current } \\ R & \text { Surface charge-transfer resistance } \\ C & \text { Surface double-layer capacitance } \\ M_{\mathrm{S}} & \text { Saturated magnetic susceptibility } \\ H_{1 / 2} & \text { Applied field strength corresponding to half of } M_{\mathrm{S}} \\ \mathrm{RT} & \text { Room temperature } \\ R^{2} & \text { Correlation factor } \\ & \end{array}$

\section{References}

1. Yasuoka, S.; Magari, Y.; Murata, T.; Tanaka, T.; Ishida, J.; Nakamura, H.; Nohma, T.; Kihara, M.; Baba, Y.; Teraoka, H. Development of high-capacity nickel-metal hydride batteries using superlattice hydrogen-absorbing alloys. J. Power Sources 2006, 156, 662-666. [CrossRef]

2. Teraoka, H. Development of Low Self-Discharge Nickel-Metal Hydride Battery. Available online: http: //www.scribd.com/doc/9704685/Teraoka-Article-En (accessed on 9 April 2016).

3. Kai, T.; Ishida, J.; Yasuoka, S.; Takeno, K. The effect of nickel-metal hydride battery's characteristics with structure of the alloy. In Proceedings of the 54th Battery Symposium in Japan, Osaka, Japan, 7-9 October 2013; p. 210.

4. Takasaki, T.; Nishimura, K.; Saito, M.; Fukunaga, H.; Iwaki, T.; Sakai, T. Cobalt-free nickel-metal hydride battery for industrial applications. J. Alloys Compd. 2013, 580, S378-S381. [CrossRef]

5. Teraoka, H. Development of Ni-MH EThSS with Lifetime and Performance Estimation Technology. Presented at the 34th International Battery Seminar \& Exhibit, Fort Lauderdale, FL, USA, 20-23 March 2017.

6. Teraoka, H. Ni-MH Stationary Energy Storage: Extreme Temperature \& Long Life Developments. Presented at the 33th International Battery Seminar \& Exhibit, Fort Lauderdale, FL, USA, 21-24 March 2016.

7. Teraoka, H. Development of Highly Durable and Long Life Ni-MH Batteries for Energy Storage Systems. Presented at the 32th International Battery Seminar \& Exhibit, Fort Lauderdale, FL, USA, 9-12 March 2015.

8. Ouchi, T.; Young, K.; Moghe, D. Reviews on the Japanese Patent Applications regarding nickel/metal hydride batteries. Batteries 2016, 2, 21. [CrossRef]

9. Kadir, K.; Sakai, T.; Uehara, I. Synthesis and structure determination of a new series of hydrogen storage alloys; $\mathrm{RMg}_{2} \mathrm{Ni}_{9}\left(\mathrm{R}=\mathrm{La}, \mathrm{Ce}, \mathrm{Pr}, \mathrm{Nd}, \mathrm{Sm}\right.$ and $\mathrm{Gd}$ ) built from $\mathrm{MgNi}_{2}$ Laves-type layers alternating with $\mathrm{AB}_{5}$ layers. J. Alloys Compd. 1997, 257, 115-121. [CrossRef] 
10. Kadir, K.; Kuriyama, N.; Sakai, T.; Uehara, I.; Eriksson, L. Structural investigation and hydrogen capacity of $\mathrm{CaMg}_{2} \mathrm{Ni}_{9}$ : A new phase in the $\mathrm{AB}_{2} \mathrm{C}_{9}$ system isostructural with $\mathrm{LaMg}_{2} \mathrm{Ni}_{9}$. J. Alloys Compd. 1999, 284, 145-154. [CrossRef]

11. Kadir, K.; Sakai, T.; Uehara, I. Structural investigation and hydrogen storage capacity of $\mathrm{LaMg}_{2} \mathrm{Ni}_{9}$ and $\left(\mathrm{La}_{0.65} \mathrm{Ca}_{0.35}\right)\left(\mathrm{Mg}_{1.32} \mathrm{Ca}_{0.68}\right) \mathrm{Ni}_{9}$ of the $\mathrm{AB}_{2} \mathrm{C}_{9}$ type structure. J. Alloys Compd. 2000, 302, 112-117.

12. Hayakawa, H.; Akiba, E.; Gotho, M.; Kohno, T. Crystal structure of hydrogen storage alloys, La-Mg-Ni $(x=3-4)$ system. Jpn. Inst. Met. 2005, 69, 170-178. (In Japanese) [CrossRef]

13. Kohno, T.; Yoshida, H.; Kawashima, F.; Inaba, T.; Sakai, I.; Yamamoto, M.; Kanda, M. Hydrogen storage properties of new ternary system alloys: $\mathrm{La}_{2} \mathrm{MgNi}_{9}, \mathrm{La}_{5} \mathrm{Mg}_{2} \mathrm{Ni}_{23}, \mathrm{La}_{3} \mathrm{MgNi}_{14}$. J. Alloys Compd. 2000, 311, L5-L7. [CrossRef]

14. Yoshida, H.; Yamamoto, M.; Sakai, I.; Inaba, T.; Takabayashi, J.; Irie, S.; Suzuki, H.; Takeno, K. Hydrogen Storage Alloy, Alkali Secondary Battery, Hybrid Car and Electric Vehicle. Jpn. Patent 069554, 2002.

15. Inaba, T.; Sakai, I.; Yoshida, H.; Takabayashi, J.; Yamamoto, M.; Suzuki, H.; Irie, S.; Takeno, K. Nickel Hydrogen Secondary Battery, Hybrid Car and Electric Vehicle. Jpn. Patent 083593, 2002.

16. Kawashima, F.; Sakamoto, T.; Arai, T. Hydrogen Storage Alloy and Nickel-Hydrogen Secondary Battery Using the Same. Jpn. Patent 105563, 2002.

17. Liao, B.; Lei, Y.; Chen, L.; Lu, G.; Pan, H.; Wang, Q. A study on the structure and electrochemical properties of $\mathrm{La}_{2} \mathrm{Mg}\left(\mathrm{Ni}_{0.95} \mathrm{M}_{0.05}\right)_{9}(\mathrm{M}=\mathrm{Co}, \mathrm{Mn}, \mathrm{Fe}, \mathrm{Al}, \mathrm{Cu}, \mathrm{Sn})$ hydrogen storage electrode alloys. J. Alloys Compd. 2004, 376, 186-195. [CrossRef]

18. Pan, H.; Liu, Y.; Gao, M.; Lei, Y.; Wang, Q. Electrochemical properties of the $\mathrm{La}_{0.7} \mathrm{Mg}_{0.3} \mathrm{Ni}_{2.65-x} \mathrm{Mn}_{0.1} \mathrm{Co}_{0.75} \mathrm{Al}_{x}$ $(x=0-5)$ hydrogen storage alloy electrode. J. Electrochem. Soc. 2005, 152, A326-A332. [CrossRef]

19. Liao, B.; Lei, Y.; Chen, L.; Lu, G.; Pan, H.; Wang, Q. The effect of Al substitution for Ni on the structure and electrochemical properties of $\mathrm{AB}_{3}$-type $\mathrm{La}_{2} \mathrm{Mg}\left(\mathrm{Ni}_{1-x} \mathrm{Al}_{x}\right)_{9}(x=0-0.05)$ alloys. J. Alloys Compd. 2005, 404-406, 665-668. [CrossRef]

20. Qiu, S.; Chu, H.; Zhang, Y.; Qi, Y.; Sun, L.; Xu, F. Investigation on the structure and electrochemical properties of $\mathrm{AB}_{3}$-type La-Mg-Ni-Co-based hydrogen storage composites. J. Alloys Compd. 2008, 462, 392-397. [CrossRef]

21. Dong, Z.; Ma, L.; Shen, X.; Wang, L.; Wu, Y.; Wang, L. Cooperative effect of Co and Al on the microstructure and electrochemical properties of $\mathrm{AB}_{3}$-type hydrogen storage electrode alloys for advanced $\mathrm{MH} / \mathrm{Ni}$ secondary battery. J. Alloys Compd. 2011, 36, 893-900. [CrossRef]

22. Belgacem, Y.B.; Khaldi, C.; Lamloumi, J. The effect of the discharge rate on the electrochemical properties of $\mathrm{AB}_{3}$-type hydrogen storage alloy as anode in nickel-metal hydride batteries. Int. J. Hydrogen Energy 2017, 42, 12797-12807. [CrossRef]

23. Liu, Z.; Yan, X.; Wang, N.; Chai, Y.; Hou, D. Cyclic stability and high rate discharge performance of $(\mathrm{La}, \mathrm{Mg})_{5} \mathrm{Ni}_{19}$ multiphase alloy. Int. J. Hydrogen Energy 2011, 36, 4370-4374. [CrossRef]

24. Guo, X.; Luo, Y.; Gao, Z.; Zhang, G.; Kang, L. The effect of Mg on the microstructure and electrochemical properties of $\mathrm{La}_{0.8-x} \mathrm{Gd}_{0.2} \mathrm{Mg}_{x} \mathrm{Ni}_{3.3} \mathrm{Co}_{0.3} \mathrm{Al}_{0.1}(x=0-0.4)$ hydrogen storage alloys. Funct. Mater. 2012, 43, 2450-2455. (In Chinese)

25. Zhao, Y.; Han, S.; Li, Y.; Liu, J.; Zhang, L.; Yang, S.; Ke, D. Characterization and improvement of electrochemical properties of $\operatorname{Pr}_{5} \mathrm{Co}_{19}$-type single-phase $\mathrm{La}_{0.84} \mathrm{Mg}_{0.16} \mathrm{Ni}_{3.80}$ alloy. Electrochim. Acta 2015, 152, 265-273. [CrossRef]

26. Li, Y.; Zhang, Y.; Ren, H.; Liu, Z.; Sun, H. Mechanism of distinct high rate dischargeability of $\mathrm{La}_{4} \mathrm{MgNi}_{19}$ electrode alloys prepared by casting and rapid quenching followed by annealing treatment. Int. J. Hydrogen Energy 2016, 41, 18571-18581. [CrossRef]

27. Xue, C.; Zhang, L.; Fan, Y.; Fan, G.; Liu, B.; Han, S. Phase transformation and electrochemical hydrogen storage performance of $\mathrm{La}_{3} \mathrm{RMgNi}_{19}(\mathrm{R}=\mathrm{La}, \mathrm{Pr}, \mathrm{Nd}, \mathrm{Sm}, \mathrm{Gd}$, and $\mathrm{Y})$ alloys. Int. J. Hydrogen Energy 2017, 42, 6051-6064. [CrossRef]

28. Liu, J.; Han, S.; Li, Y.; Zhang, L.; Zhao, Y.; Yang, S.; Liu, B. Phase structures and electrochemical properties of La-Mg-Ni-based hydrogen storage alloys with superlattice structure. Int. J. Hydrogen Energy 2016, 41, 20261-20275. [CrossRef]

29. Yan, H.; Xiong, W.; Wang, L.; Li, B.; Li, J.; Zhao, X. Investigations on $\mathrm{AB}_{3^{-}}, \mathrm{A}_{2} \mathrm{~B}_{7}-$ and $\mathrm{A}_{5} \mathrm{~B}_{19}$-type La-Y-Ni system hydrogen storage alloys. Int. J. Hydrogen Energy 2017, 42, 2257-2264. [CrossRef] 
30. Young, K.; Yasuoka, S. Past, present, and future of metal hydride alloys in nickel-metal hydride batteries. In Proceedings of the 14th International Symposium on Metal-Hydrogen Systems, Manchester, UK, 21-25 July 2014.

31. Young, K.; Chang, S.; Lin, X. C14 Laves phase metal hydride alloys for Ni/MH batteries applications. Batteries 2017, 3, 27. [CrossRef]

32. Young, K.; Wong, D.F.; Wang, L.; Nei, J.; Ouchi, T.; Yasuoka, S. Mn in misch-metal based superlattice metal hydride alloy_Part 1 Structural, hydrogen storage and electrochemical properties. J. Power Sources 2015, 277, 426-432. [CrossRef]

33. Wang, L.; Young, K.; Meng, T.; Ouchi, T.; Yasuoka, S. Partial substitution of cobalt for nickel in mixed rare earth metal based superlattice hydrogen absorbing alloy-Part 1 structural, hydrogen storage and electrochemical properties. J. Alloys Compd. 2016, 660, 407-415. [CrossRef]

34. Young, K.; Wong, D.F.; Wang, L.; Nei, J.; Ouchi, T.; Yasuoka, S. Mn in misch-metal based superlattice metal hydride alloy_Part $2 \mathrm{Ni} / \mathrm{MH}$ battery performance and failure mechanism. J. Power Sources 2015, 277, 433-442. [CrossRef]

35. Wang, L.; Young, K.; Meng, T.; English, N.; Yasuoka, S. Partial substitution of cobalt for nickel in mixed rare earth metal based superlattice hydrogen absorbing alloy-Part 2 battery performance and failure mechanism. J. Alloys Compd. 2016, 664, 417-427. [CrossRef]

36. Yasuoka, S.; Ishida, J.; Kai, T.; Kajiwara, T.; Doi, S.; Yamazaki, T.; Kishida, K.; Inui, H. Function of aluminum in crystal structure of rare earth-Mg-Ni hydrogen-absorbing alloy and deterioration mechanism of $\mathrm{Nd}_{0.9} \mathrm{Mg}_{0.1} \mathrm{Ni}_{3.4}$ and $\mathrm{Nd}_{0.9} \mathrm{Mg}_{0.1} \mathrm{Ni}_{3.3} \mathrm{Al}_{0.2}$ alloys. Int. J. Hydrogen Energy 2017, 42, 11574-11583. [CrossRef]

37. Yasuoka, S.; Ishida, J.; Kishida, K.; Inui, H. Effects of cerium on the hydrogen absorption-desorption properties of rare earth-Mg-Ni hydrogen-absorbing alloys. J. Power Sources 2017, 346, 56-62. [CrossRef]

38. Zhang, Q.A.; Lei, Y.Q.; Wang, C.S.; Wang, F.S.; Wang, Q.D. Structure of the secondary phase and its effects on hydrogen-storage properties in a $\mathrm{Ti}_{0.7} \mathrm{Zr}_{0.2} \mathrm{~V}_{0.1} \mathrm{Ni}$ alloy. J. Power Sources 1998, 75, 288-291. [CrossRef]

39. Jurczyk, M.; Jankowska, E.; Makowiecka, M.; Wieczorek, I. Electrode characteristics of nanocrystalline TiFe-type alloys. J. Alloys Compd. 2003, 354, L1-L4. [CrossRef]

40. Zhang, Q.A.; Lei, Y.Q.; Yang, X.G.; Ren, K.; Wang, Q.D. Annealing treatment of $\mathrm{AB}_{2}$-type hydrogen storage alloys: I. crystal structures. J. Alloys Compd. 1999, 292, 236-240. [CrossRef]

41. Zhang, Q.A.; Lei, Y.Q.; Yang, X.G.; Du, Y.L.; Wang, Q.D. Effects of annealing treatment on phase structures, hydrogen absorption-desorption characteristics and electrochemical properties of a $\mathrm{V}_{3} \mathrm{TiNi}_{0.56} \mathrm{Hf}_{0.24} \mathrm{Mn}_{0.15} \mathrm{Cr}_{0.1}$ alloy. J. Alloys Compd. 2000, 305, 125-129. [CrossRef]

42. Yang, X.G.; Zhang, Q.A.; Shu, K.Y.; Du, Y.L.; Lei, Y.Q.; Wang, Q.D.; Zhang, W.K. The effect of annealing on the electrochemical; properties of $\mathrm{Zr}_{0.5} \mathrm{Ti}_{0.5} \mathrm{Mn}_{0.5} \mathrm{~V}_{0.3} \mathrm{Co}_{0.2} \mathrm{Ni}_{1.1}$ alloy electrode. J. Power Sources 2000, 90, 170-175. [CrossRef]

43. Young, K.; Ouchi, T.; Huang, B.; Chao, B.; Fetcenko, M.A.; Bendersky, L.A.; Wang, K.; Chiu, C. The correlation of $\mathrm{C} 14 / \mathrm{C} 15$ phase abundance and electrochemical properties in the $\mathrm{AB}_{2}$ alloys. J. Alloys Compd. 2010, 506, 841-848. [CrossRef]

44. Pan, H.; Liu, Y.; Gao, M.; Zhu, Y.; Lei, Y.; Wang, Q. A study on the effect of annealing treatment on the electrochemical properties of $\mathrm{La}_{0.67} \mathrm{Mg}_{0.33} \mathrm{Ni}_{2.5} \mathrm{Co}_{0.5}$ alloy electrode. Int. J. Hydrogen Energy 2003, 28, 113-117. [CrossRef]

45. Yang, Z.P.; Li, Q.; Zhao, X.J. Influence of magnetic annealing on electrochemical performance of $\mathrm{La}_{0.67} \mathrm{Mg}_{0.33} \mathrm{Ni}_{3.0}$ hydride electrode. J. Alloys Compd. 2013, 558, 99-104. [CrossRef]

46. Hu, W.; Denys, R.V.; Nwakwuo, C.C.; Holm, T.; Maehlen, J.P.; Solberg, J.K.; Yartys, V.A. Annealing effect on phase composition and electrochemical properties of the $\mathrm{Co}$-free $\mathrm{La}_{2} \mathrm{MgNi}_{9}$ anode for $\mathrm{Ni}$-metal hydride batteries. Electrochim. Acta 2013, 96, 27-133. [CrossRef]

47. Li, P.; Zhang, J.; Zhai, F.; Ma, G.; Xu, L.; Qu, X. Effect of annealing treatment on the anti-pulverization and anti-corrosion properties of $\mathrm{La}_{0.67} \mathrm{Mg}_{0.33} \mathrm{Ni}_{2.5} \mathrm{Co}_{0.5}$ hydrogen storage alloy. J. Rare Earths 2015, 33, 417-424. [CrossRef]

48. Young, K.; Ouchi, T.; Huang, B. Effects of annealing and stoichiometry to (Nd, $\mathrm{Mg})(\mathrm{Ni}, \mathrm{Al})_{3.5}$ metal hydride alloys. J. Power Sources 2012, 215, 152-159. [CrossRef]

49. Balcerzak, M.; Nowak, M.; Jurczyk, M. Hydrogenation and electrochemical studies of La-Mg-Ni alloy. Int. J. Hydrogen Energy 2017, 42, 1436-1443. [CrossRef] 
50. Xiong, W.; Uan, H.; Wang, L.; Zhao, X.; Li, J.; Li, B.; Wang, Y. Effects of annealing temperature on the structure and properties of the $\mathrm{LaY}_{2} \mathrm{Ni}_{10} \mathrm{Mn}_{0.5}$ hydrogen storage alloy. Int. J. Hydrogen Energy 2017, 42, 15319-15327. [CrossRef]

51. Zhang, Y.; Yang, T.; Zhai, T.; Yuan, Z.; Zhang, G.; Guo, S. Effects of stoichiometric ratio La/Mg on structures and electrochemical performances of as-cast and annealed La-Mg-Ni-based $\mathrm{A}_{2} \mathrm{~B}_{7}$-type electrode alloy. Trans. Nonferrous Met. Soc. China 2015, 25, 1968-1977. [CrossRef]

52. Hayakawa, H.; Enoki, H.; Akiba, E. Annealing conditions with Mg vapor-pressure control and hydrogen storage characteristic of $\mathrm{La}_{4} \mathrm{MgNi}_{19}$ hydrogen storage alloy. Jpn. Inst. Met. 2006, 70, 158-161. (In Japanese) [CrossRef]

53. Hu, W.K.; Kim, D.M.; Jeon, S.W.; Lee, J.Y. Effect of annealing treatment on electrochemical properties of Mm-based hydrogen storage alloys for Ni/MH batteries. J. Alloys Compd. 1998, 270, 255-264. [CrossRef]

54. Ma, Z.; Qiu, J.; Chen, L.; Lei, Y. Effects of annealing on microstructure and electrochemical properties of the low Co-containing alloy MI(NiCoMnAlFe) $)_{5}$ for Ni/MH battery electrode. J. Power Sources 2004, 125, $267-272$. [CrossRef]

55. Zhou, Z.; Song, Y.; Cui, S.; Huang, C.; Qian, W.; Lin, C.; Zhang, Y.; Lin, Y. Effect of annealing treatment on structure and electrochemical performance of quenched $\mathrm{MmNi}_{4.2} \mathrm{Co}_{0.3} \mathrm{Mn}_{0.4} \mathrm{Al}_{0.3} \mathrm{Mg}_{0.03}$ hydrogen storage alloy. J. Alloys Compd. 2010, 501, 47-53. [CrossRef]

56. Nei, J.; Young, K.; Salley, S.O.; Ng, K.Y.S. Effects of annealing on $\mathrm{Zr}_{8} \mathrm{Ni}_{19} \mathrm{X}_{2}$ (X= Ni, Mg, Al, Sc, V, Mn, Co, Sn, La and Hf): Structural characteristics. J. Alloys Compd. 2012, 516, 144-152. [CrossRef]

57. Nei, J.; Young, K.; Salley, S.O.; NG, K.Y.S. Effects of annealing on $\mathrm{Zr}_{8} \mathrm{Ni}_{19} \mathrm{X}_{2}(\mathrm{X}=\mathrm{Ni}, \mathrm{Mg}, \mathrm{Al}, \mathrm{Sc}, \mathrm{V}, \mathrm{Mn}, \mathrm{Co}$, Sn, La and Hf): Hydrogen storage and electrochemical properties. Int. J. Hydrogen Energy 2012, 37, 8418-8427. [CrossRef]

58. Young, K.; Ouchi, T.; Nei, J.; Wang, L. Annealing effects on Laves phase-related body-centered-cubic solid solution metal hydride alloys. J. Alloys Compd. 2016, 654, 216-225. [CrossRef]

59. Crivello, J.-C.; Zhang, J.; Latroche, M. Structural stability of $\mathrm{AB}_{y}$ phases in the (La,Mg)-Ni system obtained by density functional theory calculations. J. Phys. Chem. 2011, 115, 25470-25478.

60. Wong, D.F.; Young, K. Phase stability of superlattice metal hydride alloy estimated by first principle calculation. Unpublished work, 2017.

61. Zhang, L.; Zhang, J.; Han, S.; Li, Y.; Yang, S.; Liu, J. Phase transformation and electrochemical properties of $\mathrm{La}_{0.70} \mathrm{Mg}_{0.30} \mathrm{Ni}_{3.3}$ super-stacking metal hydride alloy. Intermetallics 2015, 58, 65-70.

62. Li, F.; Young, K.; Ouchi, T.; Fetcenko, M.A. Annealing effects on structural and electrochemical properties of $(\mathrm{LaPrNdZr})_{0.83} \mathrm{Mg}_{0.17}(\mathrm{NiCoAlMn})_{3.3}$ alloy. J. Alloys Compd. 2009, 471, 371-377. [CrossRef]

63. Young, K.; Wang, L.; Yan, S.; Liao, X.; Meng, T.; Shen, H.; May, W.C. Fabrications of high-capacity alpha-Ni(OH) $)_{2}$. Batteries 2017, 3, 6. [CrossRef]

64. Young, K.; Wu, A.; Qiu, Z.; Tan, J.; Mays, W. Effects of $\mathrm{H}_{2} \mathrm{O}_{2}$ addition to the cell balance and self-discharge of $\mathrm{Ni} / \mathrm{MH}$ batteries with $\mathrm{AB}_{5}$ and $\mathrm{A}_{2} \mathrm{~B}_{7}$ alloys. Int. J. Hydrogen Energy 2012, 37, 9882-9891. [CrossRef]

65. Young, K.; Koch, J.M.; Wan, C.; Denys, R.V.; Yartys, V.A. Cell performance comparison between C14- and C15-predominated $\mathrm{AB}_{2}$ metal hydride alloys. Batteries 2017, 3, 29. [CrossRef]

66. Charbonnier, V.; Monnier, J.; Zhang, J.; Paul-Boucour, V.; Joiret, S.; Puga, B.; Goubault, L.; Bernard, P.; Latroche, M. Relationship between $\mathrm{H}_{2}$ sorption properties and aqueous corrosion mechanisms in $\mathrm{A}_{2} \mathrm{~B}_{7}$ hydride forming alloys (A = Y, Gd or Sm). J. Power Sources 2016, 326, 146-155. [CrossRef]

67. Tang, R.; Wei, X.; Liu, Y.; Zhu, C.; Zhu, J.; Yu, G. Effect of the Sm content on the structure and electrochemical properties of $\mathrm{La}_{1.3-x} \mathrm{Sm}_{x} \mathrm{CaMg}_{0.7} \mathrm{Ni}_{9}(x=0-0.3)$ hydrogen storage alloys. J. Power Sources 2006, 155, 456-460.

68. Ping, L.; Hou, Z.; Yang, T.; Shang, H.; Qu, X.; Zhang, Y. Structure and electrochemical hydrogen storage characteristics of the as-cast and annealed $\mathrm{La}_{0.8-x} \mathrm{Sm}_{x} \mathrm{Mg}_{0.2} \mathrm{Ni}_{3.15} \mathrm{Co}_{0.2} \mathrm{Al}_{0.1} \mathrm{Si}_{0.05}(x=0-0.4)$ alloys. J. Rare Earths 2012, 30, 696-704.

69. Zhang, Y.; Hou, Z.; Li, B.; Ren, H.; Zhang, G.; Zhao, D. An investigation on electrochemical hydrogen storage performances of the as-cast and -annealed $\mathrm{La}_{0.8-x} \mathrm{Sm}_{x} \mathrm{Mg}_{0.2} \mathrm{Ni}_{3.35} \mathrm{Al}_{0.1} \mathrm{Si}_{0.05}(x=0-0.4)$ alloys. J. Alloys Compd. 2012, 537, 175-182. [CrossRef]

70. Zhang, Y.; Li, P.; Yang, T.; Zhai, T.; Yuan, Z.; Guo, S. Effects of substituting La with M (M = Sm, Nd, Pr) on electrochemical hydrogen storage characteristics of $\mathrm{A}_{2} \mathrm{~B}_{7}$-type electrode alloys. Trans. Nonferrous Met. Soc. China 2014, 24, 4012-4022. [CrossRef] 
71. Liu, J.; Han, S.; Li, Y.; Zhao, X.; Yang, S.; Zhao, Y. Cooperative effects of Sm and Mg on electrochemical performance of La-Mg-Ni-based alloys with $\mathrm{A}_{2} \mathrm{~B}_{7}$ - and $\mathrm{A}_{5} \mathrm{~B}_{19}$-type super-stacking structure. Int. J. Hydrogen Energy 2015, 40, 1116-1127. [CrossRef]

72. Young, K.; Ouchi, T.; Wang, L.; Wong, D.F. The effects of Al substitution on the phase abundance, structure and electrochemical performance of $\mathrm{La}_{0.7} \mathrm{Mg}_{0.3} \mathrm{Ni}_{2.8} \mathrm{Co}_{0.5-x} \mathrm{Al}_{x}(x=0,0.1,0.2)$ alloys. J. Power Sources 2015, 279, 172-179. [CrossRef]

73. Zhang, L.; Ding, Y.; Zhao, Y.; Du, W.; Li, Y.; Yang, S.; Han, S. Phase structure and cycling stability of $\mathrm{A}_{2} \mathrm{~B}_{7}$ superlattice $\mathrm{La}_{0.60} \mathrm{Sm}_{0.15} \mathrm{Mg}_{0.25} \mathrm{Ni}_{3.4}$ metal hydride alloy. Int. J. Hydrogen Energy 2016, 41, 1791-1800. [CrossRef]

74. Young, K.; Ouchi, T.; Koch, J.; Fetcenko, M.A. The role of Mn in C14 Laves phase multi-component alloys for NiMH battery application. J. Alloys Compd. 2009, 477, 749-758. [CrossRef]

75. Osumi, Y. Suiso Kyuzou Goukin; Agune Technology Center: Tokyo, Japan, 1999; p. 218. (In Japanese)

76. Schlapbach, L.; Züttel, A. Hydrogen-storage materials for mobile applications. Nature 2001, 414, 353-358. [CrossRef] [PubMed]

77. Young, K.; Ouchi, T.; Nei, J.; Moghe, D. The importance of rare-earth additions in Zr-based $\mathrm{AB}_{2}$ metal hydride alloys. Batteries 2016, 2, 25. [CrossRef]

78. Stucki, F.; Schlapbach, L. Magnetic properties of $\mathrm{LaNi}_{5}, \mathrm{FeTi}, \mathrm{Mg}_{2} \mathrm{Ni}$ and their hydrides. J. Less-Comm. Met. 1980, 74, 143-151. [CrossRef]

79. Young, K.; Huang, B.; Regmi, R.K.; Lawes, G.; Liu, Y. Comparisons of metallic clusters imbedded in the surface of $\mathrm{AB}_{2}, \mathrm{AB}_{5}$, and $\mathrm{A}_{2} \mathrm{~B}_{7}$ alloys. J. Alloys Compd. 2010, 506, 831-840. [CrossRef]

80. Young, K.; Chao, B.; Pawlik, D.; Shen, H.T. Transmission electron microscope studies in the surface oxide on the La-containing $\mathrm{AB}_{2}$ metal hydride alloy. J. Alloys Compd. 2016, 672, 356-365. [CrossRef]

81. Meng, T.; Young, K.; Hu, C.; Reichman, B. Effects of alkaline pre-etching to metal hydride alloys. Batteries 2017, 3, 30. [CrossRef]

82. Young, K.; Nei, J.; Wan, C.; Denys, R.V.; Yartys, V.A. Comparison of C15- and C15-predominated AB 2 metal hydride alloys for electrochemical applications. Batteries 2017, 3, 22. [CrossRef]

(C) 2017 by the authors. Licensee MDPI, Basel, Switzerland. This article is an open access article distributed under the terms and conditions of the Creative Commons Attribution (CC BY) license (http:/ / creativecommons.org/licenses/by/4.0/). 